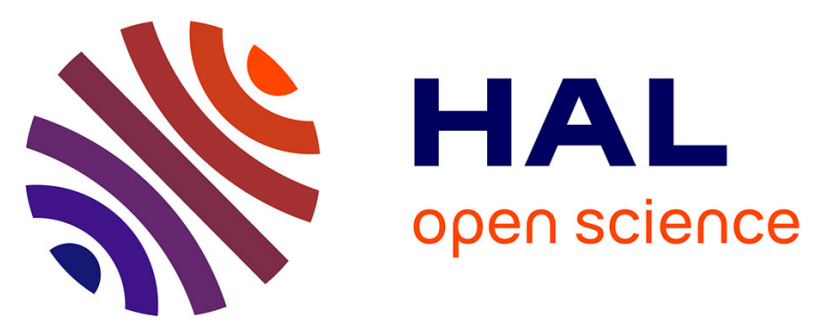

\title{
Inhibitors Targeting STAT5 Signaling in Myeloid Leukemias: New Tetrahydroquinoline Derivatives with Improved Antileukemic Potential
}

Marion Polomski, Marie Brachet-Botineau, Ludovic Juen, Marie-Claude Viaud-Massuard, Fabrice Gouilleux, Gildas Prié

\section{To cite this version:}

Marion Polomski, Marie Brachet-Botineau, Ludovic Juen, Marie-Claude Viaud-Massuard, Fabrice Gouilleux, et al.. Inhibitors Targeting STAT5 Signaling in Myeloid Leukemias: New Tetrahydroquinoline Derivatives with Improved Antileukemic Potential. ChemMedChem, 2020, 10.1002/cmdc.202000841 . hal-03047849

\author{
HAL Id: hal-03047849 \\ https://hal.science/hal-03047849
}

Submitted on 30 Oct 2021

HAL is a multi-disciplinary open access archive for the deposit and dissemination of scientific research documents, whether they are published or not. The documents may come from teaching and research institutions in France or abroad, or from public or private research centers.
L'archive ouverte pluridisciplinaire HAL, est destinée au dépôt et à la diffusion de documents scientifiques de niveau recherche, publiés ou non, émanant des établissements d'enseignement et de recherche français ou étrangers, des laboratoires publics ou privés. 


\title{
Inhibitors Targeting STAT5 Signaling in Myeloid Leukemias: New Tetrahydroquinoline Derivatives with Improved Antileukemic Potential
}

\author{
Marion Polomski ${ }^{+}{ }^{[a]}$ Marie Brachet-Botineau ${ }^{+},{ }^{[b]}$ Ludovic Juen, $^{[a]}$ \\ Marie-Claude Viaud-Massuard, ${ }^{[a]}$ Fabrice Gouilleux, ${ }^{[b]}$ and Gildas Prié ${ }^{[a]}$
}

\begin{abstract}
Signal transducers and activators of transcription $5 \mathrm{~A}$ and $5 \mathrm{~B}$ (STAT5A and STAT5B) are two closely related STAT family members that are crucial downstream effectors of tyrosine kinase oncoproteins such as FLT3-ITD in acute myeloid leukemia (AML) and BCR-ABL in chronic myeloid leukemia (CML). We recently developed and reported the synthesis of a first molecule called $17 \mathrm{f}$ that selectively inhibits STAT5 signaling in myeloid leukemia cells and overcomes their resistance to
\end{abstract}

chemotherapeutic agents. To improve the antileukemic effect of $17 \mathrm{f}$, we synthesized ten analogs of this molecule and analyzed their impact on cell growth, survival, chemoresistance and STAT5 signaling. Two compounds, $7 a$ and $7 a^{\prime}$, were identified as having similar or higher antileukemic effects in various $A M L$ and $C M L$ cell lines. Both molecules were found to be more effective than $17 \mathrm{f}$ at inhibiting STAT5 activity/ expression and suppressing the chemoresistance of CML.

\section{Introduction}

Among the STAT family members, STAT5A and STAT5B proteins play a critical role in the development of hematologic cancers that affect lymphoid and myeloid lineages. ${ }^{[1]}$ Persistent tyrosine phosphorylation of STAT5A/5B (P-Y-STAT5) has been found in hematopoietic cancers driven by tyrosine kinase oncogenes (TKO) such as BCR-ABL in chronic myeloid and acute lymphoid leukemias (CML and $\left.\mathrm{Ph}^{+} \mathrm{ALL}\right), \mathrm{FLT3}$-internal tandem duplication (FLT3-ITD) in acute myeloid leukemia (AML) and JAK2 ${ }^{\mathrm{V} 617 \mathrm{~F}}$ in myeloproliferative neoplasms (MPN).$^{[2-4]}$ In addition, gain of function (GOF) mutations of STAT5B have been described in different hematopoietic malignancies affecting the lymphoid compartment. This is best illustrated by the presence of the recurrent $\mathrm{N} 642 \mathrm{H}$ mutation of STAT5B in some T cell leukemias. ${ }^{[5]}$

The development of imatinib mesylate $\left(\mathrm{IM}\right.$, Glivec $\left.^{\circledR}\right)$ and related $B C R-A B L$ kinase inhibitors such as dasatinib, nilotinib, bosutinib and ponatinib has been a major breakthrough in the treatment of CML. ${ }^{[6-10]} \mathrm{IM}$ leads to complete inhibition of BCR-

[a] M. Polomski, Dr. L. Juen, Prof. M.-C. Viaud-Massuard, Dr. G. Prié Equipe IMT "Innovation Moléculaire et Thérapeutique" - GICC EA7501 Université de Tours-Labex SYNORG

Faculté de Pharmacie

31 av. Monge, 37200 Tours (France)

E-mail: gildas.prie@univ-tours.fr

[b] Dr. M. Brachet-Botineau, ${ }^{+}$Dr. F. Gouilleux

Equipe LNOx "Niche Leucémique \& Métabolisme Oxydatif" - GICC ERL 7001 CNRS

Université de Tours, Faculté de Médecine

Bâtiment Dutrochet, 10bis bvd Tonnellé, 37032 Tours (France)

$\left.{ }^{[}\right]$These authors contributed equally to this work.

Supporting information for this article is available on the WWW under https://doi.org/10.1002/cmdc.202000841. Detailed synthesis strategic pathways starting from 2-aminophenylboronic acid and 2-chloroaniline to reach 2-pyridinyl analog in position 8 on THQ ring, NMR spectra and biological evaluation of compounds $6 c, 10,13 d$ and $13 d^{\prime}$ on other AML cell lines, KG1a and MOLM-13.
ABL-dependent STAT5 activation, which is an important part of this molecule effectiveness. However, imatinib mesylate is not totally curative and is unable to completely eradicate leukemic stem cells (LSC) which is responsible of relapse of CML patients. Moreover, mutations on BCR-ABL tyrosine kinase domain occurs, which prevents $I M$ binding and promote IM resistance of CML cells. ${ }^{[11-15]}$

Mutations affecting the tyrosine kinase receptor FLT3 can be found in up to one third of AML patients. FLT3-ITD is the most frequent one and usually confers a poor prognosis. ${ }^{[16]}$ Targeting the kinase activity of FLT3 mutants has been therefore adopted to inhibit aberrant signaling in AML. First- and second-generations FLT3 inhibitors were employed as a single agent or in combination with other therapeutic drugs such as cytarabine (Ara-C) and anthracyclines in AML treatment. ${ }^{[17-20]}$ The clinical activity of some of these molecules was evidenced in patients with FLT3-mutated AML but was often transient and relapse eventually occurred. Like $B C R-A B L$, secondary mutations in FLT3 have been shown to be responsible for the loss of therapeutic response to FLT3 inhibitors. ${ }^{[21]}$ Alternative approaches targeting critical effectors of BCR-ABL and FLT3-ITD are therefore needed to cure CML and AML.

In this regard, STAT5 satisfy all criteria to be a druggable target in CML and AML diseases. ${ }^{[2,23]}$ STAT5 proteins have been shown to play a crucial role in the maintenance of CML stem cells and to promote the resistance of CML cells against TKI treatments. ${ }^{[24-27]}$ Expression of P-Y-STAT5 has also been associated with an increased risk of relapse in AML after achieving complete remission. ${ }^{[28]}$ Thus, targeting STAT5 would contribute to abrogating de novo and acquired resistance of $C M L$ and $A M L$ to chemotherapy.

Several approaches have been used to target STAT5 in leukemias. ${ }^{[23]}$ Among them, chromone- and salicylic acid-based molecules have been employed to identify selective inhibitors that bind to the SH2 domain of STAT5. ${ }^{[29-31]}$ One of them, AC-4- 
130 suppressed P-Y-STAT5 and the growth of CML and AML cells as well as tumor formation in xenograft models of AML. ${ }^{[32,33]}$ Finally, another small STAT5-SH2-binding compound containing a nucleotidic scaffold showing a therapeutic potential for prostate cancer and CML has been identified in structure-based screening studies. ${ }^{[34]}$ In a similar vein, cell-based screening assays using a library of clinically used drugs were also employed to identify the antipsychotic drug, pimozide, as a potential STAT5 inhibitor. This compound was shown to inhibit P-Y-STAT5 and survival of CML and AML cells without affecting the kinase activity of BCR-ABL or FLT3-ITD. ${ }^{[35,36]}$ Synthesis of pimozide derivatives and structure-activity relationship (SAR) studies allowed to identify compounds with enhanced inhibitory effects on STAT5 activity and CML cell growth. ${ }^{[37]}$ As repositioning drugs, antidiabetics such as pioglitazone and rosiglitazone have also been shown to possess antileukemic activity. Both synthetic compounds belong to the thiazolidinedione (TZD) class of ligands that bind to the nuclear receptor peroxisome proliferator-activated receptor gamma (PPAR $\gamma$ ). Activation of PPAR $\gamma$ by pioglitazone not only inhibits the growth of CML cells but also reduces the expression of STAT5 genes. ${ }^{[38-40]}$ Importantly, the drug combination using pioglitazone with IM triggers apoptosis of these leukemic cells suggesting that besides phosphorylation, inhibition of STAT5 expression is of prime importance for resistant CML stem cell eradication..$^{[40]}$

We used a library of PPAR agonists that were previously synthesized in our lab, to identify a hit compound that blocks P-Y-STAT5 and leukemic cell growth. 18 derivatives of this "hit" sharing a diversely substituted 4,4-dimethyl-1,2,3,4-tetrahydroquinoline scaffold, linked to an heteroaryl ring by an ethoxy chain were synthesized and tested in preclinical studies using various leukemic cell lines. Results of the cell proliferation and viability assays allowed us to select one compound called $17 \mathrm{f}$ with improved antileukemic activity. This compound is composed of a 3-pyridinyl substituted 4,4-dimethyl-1,2,3,4-tetrahydroquinoline (THQ) and indole rings, linked by an ethoxy chain attached by carbon $\mathrm{C}-5$ of the indole and nitrogen $\mathrm{N}-1$ of the THQ (Figure 1). We showed that $17 \mathrm{f}$ suppressed P-Y-STAT5 and growth of CML and AML cells. ${ }^{[4]]}$ We also demonstrated that $17 f$ sensitizes leukemic cells that acquired resistance to IM or AraC. ${ }^{[42]}$

In order to improve the antileukemic potential of $17 \mathrm{f}$, we synthesized 10 new analogs with modifications around the tetrahydroquinoline (THQ) ring and analyzed their impacts on

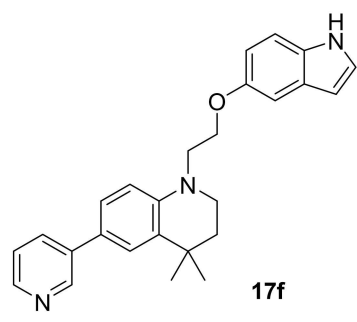

Figure 1. Compound $17 \mathrm{f}$.
$\mathrm{CML}$ and $\mathrm{AML}$ cell growth. Among these analogs, two compounds, $7 \mathrm{a}$ and $7 \mathrm{a}^{\prime}$, containing respectively a 3- and 4pyridinyl moiety in position 5 on the THQ ring, showed similar or higher growth inhibitory effects when compared to $\mathbf{1 7 f}$. We also demonstrated that $7 \mathrm{a}$ and $7 \mathrm{a}^{\prime}$ were more effective than $17 \mathrm{f}$ in blocking P-Y-STAT5 expression and activity. Lastly, both compounds showed a slightly better cytotoxic effect when combined with IM to kill CML cells that acquired resistance to this tyrosine kinase inhibitor.

\section{Chemistry}

In order to study SAR around the tetrahydroquinoline (THQ) ring, we used a convergent pathway implemented and optimized from our previously described work. This synthetic route, setting good yields, has been extended to synthesize a series of new analogs using the brominated THQ and indole rings as starting materials with the linking strategy as described previously (Scheme 1)..$^{[41]}$

To obtain these analogs series, we needed to synthetize the brominated key intermediates 4,4-dimethyl-1,2,3,4-tetrahydroquinoline 6 , with bromine on positions 5,7 and 8 . From 2bromoaniline, we performed the same method used in Juen et al. work with an acylation followed by a Friedel-Crafts alkylation to get lactam $2 \mathbf{d}$. $^{[41]}$ From 3-bromoaniline, we obtained as expected both lactam brominated on positions 5 and 7 , and isolated each isomer by purification, respectively $2 \mathrm{a}$ and $2 \mathrm{c}$. Each lactam was then reduced to the corresponding brominated THQ $\mathbf{3 a}$ a, c, d. Alcohol 4 was converted to aldehyde by 2 -iodobenzoic acid (IBX) and then filtered on amines $\mathbf{3} \mathrm{a}$ and $3 \mathrm{c}$ in the presence of $\mathrm{NaBH}(\mathrm{OAC})_{3}$, to afford by reductive amination $5 \mathrm{a}$ and $\mathbf{5 c}$. From amine $\mathbf{3 d}$, compound $\mathbf{5 d}$ was not observed, surely due to steric hindrance of the bromine in position 8 on the tetrahydroquinoline scaffold. Consequently, an alternative synthesis pathway from amine $3 \mathbf{d}$ has been developed to obtain the desired 8-brominated THQ. Finally, deprotection of $\mathbf{5} \mathrm{a}$ and $\mathbf{5} \mathrm{c}$ using potassium tert-butoxide under air (1 atm) in DMSO led to key intermediates $6 \mathrm{a}$ and $6 \mathrm{c}$, with $68 \%$ and $74 \%$ yields respectively (Scheme 2 ).

Introduction of 3- and 4-pyridinyl groups on the THQ ring of both $6 \mathrm{a}-\mathrm{c}$ by Suzuki cross-coupling afforded respectively $7 \mathrm{a}-\mathrm{c}$ and $7 a^{\prime}-c^{\prime}$ analogs with satisfying yields (40-61\%; Scheme 3).

However, as observed by Juen et al., the reaction between $6 \mathrm{a}-\mathrm{c}$ and 2-pyridinylboronic acid did not occur and only led to degradation of the starting material. To bypass this issue, we converted aryl bromides $6 \mathrm{a}-\mathrm{c}$ into pinacol boronate esters $\mathbf{8 a -}$

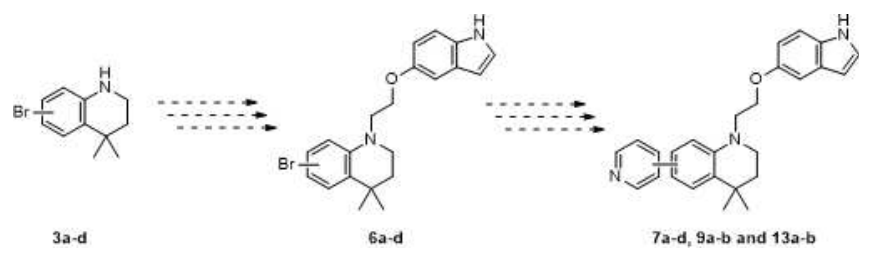

Scheme 1. Our work on new analogs. 


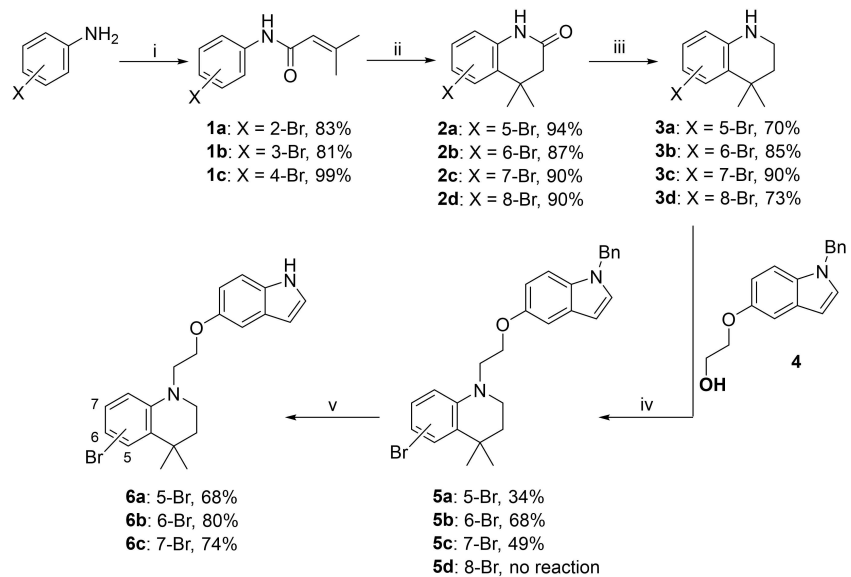

Scheme 2. Synthesis of key intermediates $6 \mathbf{a}$-c. i) 3,3-dimethylacryloyl

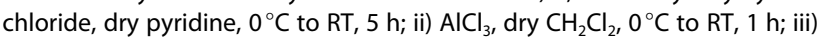
$\mathrm{BH}_{3} \cdot \mathrm{THF}$, dry toluene, $0^{\circ} \mathrm{C}$ to reflux, $5 \mathrm{~h}$; iv) 1) alcohol 4 , IBX, dry DCE, $80^{\circ} \mathrm{C}$ $2 \mathrm{~h}$; 2) filtration; 3 ) amine $3, \mathrm{NaBH}(\mathrm{OAc})_{3}, \mathrm{RT}, 3 \mathrm{~h}$; v) tBuOK, DMSO, $\mathrm{O}_{2}, \mathrm{RT}, 3 \mathrm{~h}$.

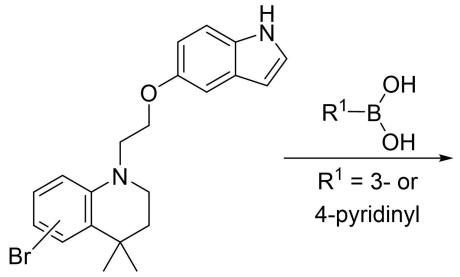

6a: $5-\mathrm{Br}$

6b: $6-\mathrm{Br}$

6c: $7-\mathrm{Br}$

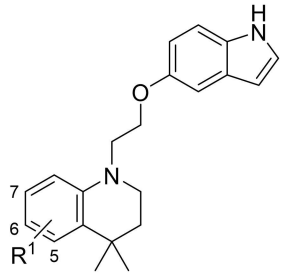

7a: 5-(3-Py), $40 \%$ 7b: $6-(3-P y), 46 \%$ 7c: $7-(3-P y), 59 \%$ 7a': 5-(4-Py), 51\% 7b': 6-(4-Py), 50\% 7c': 7-(4-Py), 61\%
Scheme 3. Synthesis of analogs $7 \mathbf{a}-\mathbf{c}$ and $\mathbf{7} \mathbf{a}^{\prime}-\mathrm{c}^{\prime}$ by Suzuki coupling from compounds $6 \mathrm{a}-\mathrm{c}$. $\mathrm{R}^{1} \mathrm{~B}(\mathrm{OH})_{2}, \mathrm{PdCl}_{2}\left(\mathrm{PPh}_{3}\right)_{2}, \mathrm{~K}_{2} \mathrm{CO}_{3}, \mathrm{DMF} /$ water, $90^{\circ} \mathrm{C}, 5 \mathrm{~h}$.

c with good yields (50-68\%). Compounds $8 \mathrm{~b}$ and $8 \mathrm{c}$ subsequently yielded $9 \mathrm{~b}$ and $9 \mathrm{c}$ after Suzuki coupling using 2bromopyridine. ${ }^{[43,44]}$ Concerning compound $9 \mathbf{b}$, this optimized procedure allowed us to improve the yield from 24 to $60 \%$ in two steps. ${ }^{[41]}$ Though, concerning pinacol boronate ester $\mathbf{8 a}$, coupling was not observed, surely due to steric hindrance between methyl groups of both pinacol boronate and THQ. Consequently, we synthesized the corresponding less hindered neopentyl boronate ester 10 from aryl bromide $6 \mathrm{a}$ and used it in the same way in Suzuki coupling with 2-bromopyridine to yield 9 a with a satisfying $71 \%$ yield (Scheme 4).

We then focused on analogs substituted in position 8 on the THQ ring. Indeed, as previously described, no reaction between amine $\mathbf{3 d}$ and alcohol $\mathbf{4}$ was observed due to the bromine position. Therefore, Suzuki cross-coupling with 3 - and 4-pyridinyl boronic acids were performed first on brominated THQ $\mathbf{3} \mathbf{d}$ to afford $\mathbf{1 1} \mathbf{d}, \mathbf{d}^{\prime}$. Thereafter classic pathway was used to reach compounds $\mathbf{1 3} \mathrm{d}_{\mathbf{1}} \mathrm{d}^{\prime}$ in two steps and unsurprisingly, the bridge formation first step gave low yields (Scheme 5).

Introduction of 2-pyridinyl ring at position 8 was a double challenge, considering known difficulties with 2-pyridinyl coupling reactions and THQ position 8 hindrance, so several

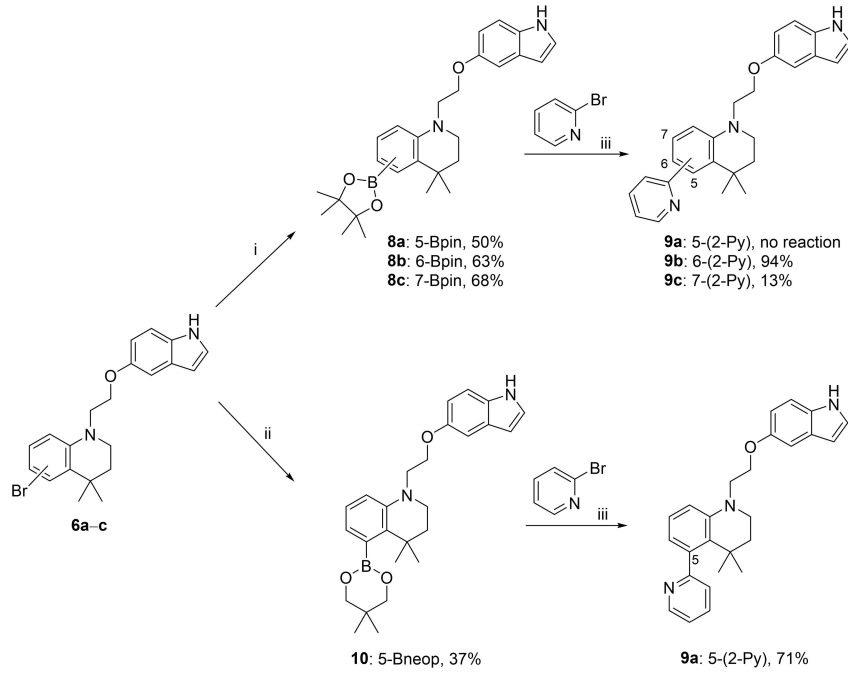

Scheme 4. Synthesis of 2-pyridinyl analogs from compounds $6 \mathrm{a}-\mathrm{c}$. i) bis (pinacolato)diboron, $\mathrm{PdCl}_{2}(\mathrm{dppf}), \mathrm{KOAc}$, dry dioxane, $100^{\circ} \mathrm{C}, 12 \mathrm{~h}$; ii) bis (neopentylglycolato)diboron, $\mathrm{PdCl}_{2}(\mathrm{dppf}), \mathrm{KOAc}$, dry dioxane, $100^{\circ} \mathrm{C}, 12 \mathrm{~h}$; iii) 2-bromopyridine, $\mathrm{PdCl}_{2}(\mathrm{dppf}), \mathrm{Na}_{2} \mathrm{CO}_{3}$, dioxane/water, $100^{\circ} \mathrm{C}, 5 \mathrm{~h}$.

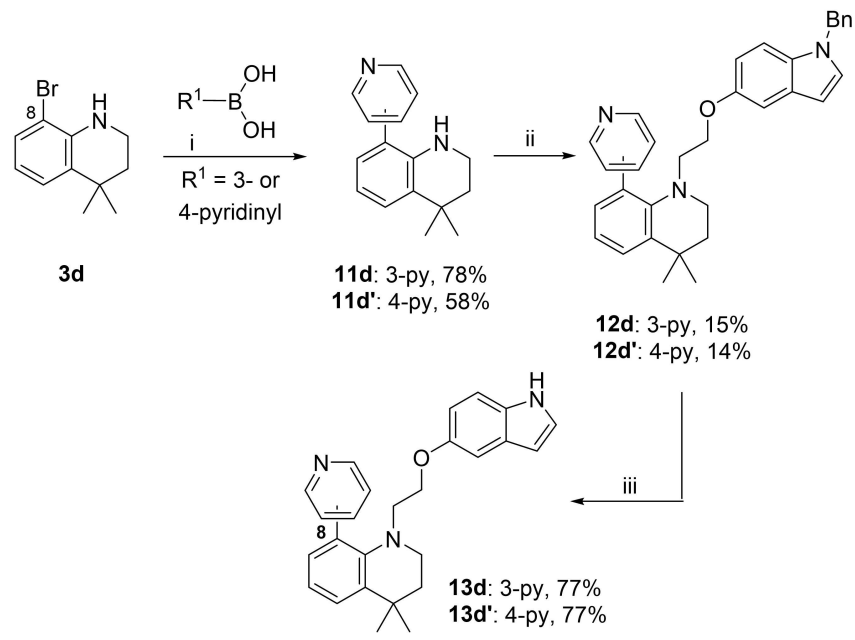

Scheme 5. Synthesis of analogs substituted at position 8 on the tetrahydroquinoline ring. i) $\mathrm{R}^{1} \mathrm{~B}(\mathrm{OH})_{2}, \mathrm{PdCl}_{2}\left(\mathrm{PPh}_{3}\right)_{2}, \mathrm{~K}_{2} \mathrm{CO}_{3}, \mathrm{DMF} /$ water, $90^{\circ} \mathrm{C}, 5 \mathrm{~h}$; ii) 1) alcohol 4, IBX, dry $\mathrm{DCE}, 80^{\circ} \mathrm{C}, 2 \mathrm{~h} ; 2$ ) filtration; 3 ) amine $12, \mathrm{NaBH}(\mathrm{OAC})_{3,}$ $\mathrm{RT}, 3 \mathrm{~h}$; iii) tBuOK, DMSO, $\mathrm{O}_{2}, \mathrm{RT}, 3 \mathrm{~h}$.

strategies were implemented. Previously described, formation of pinacol or neopentyl boronate ester were tested on aryl bromide $\mathbf{3} \mathbf{d}$, in order to perform Suzuki coupling with 2bromopyridine. However, none of these reactions occurred certainly due to interactions between the free amine hydrogen and the bromine. To avoid this, we decided to protect the amine function by a benzyl group. Two strategies were employed starting from compound $3 \mathrm{~d}$ : reductive amination using benzaldehyde in the presence of $\mathrm{NaBH}(\mathrm{OAc})_{3}$ and classical $\mathrm{N}$-alkylation from benzylbromide using sodium hydride. Unfortunately, none of the two reactions yielded the desired protected amine. Two different strategies of complete synthesis were then considered starting from 2-aminophenylboronic acid 
or 2-chloroaniline (see the Supporting Information). Synthetic route using 2 -aminophenylboronic acid permitted to obtain the THQ substituted with a 2-pyridine group in position 8 , however all attempts to yield the compound linked to indole by the ethyloxy chain failed. We explained this by the steric hindrance with the 2-pyridinyl group in this 8-position and thus by possible interaction between the hydrogen of amine function on tetrahydroquinoline scaffold and the 2-pyridine nitrogen. From 2-chloroaniline, we achieved synthesis of linked compound with chloride in position 8 on tetrahydroquinoline ring with a very low $5 \%$ yield. Then, deprotected compound was obtained and used to form the corresponding pinacol boronate or neopentyl boronate ester but all reactions failed and led to the starting chlorinated material.

\section{Results and Discussion}

In order to improve the antileukemic activity of $17 \mathrm{f}$, SAR studies were conducted with focus on the pyridinyl heterocycle bound to the tetrahydroquinoline ring. In this work, we then addressed whether changes in the nitrogen position on the pyridinyl moiety as well as changes in the position of the latter on the THQ ring might directly impact the antileukemic potential of $17 \mathrm{f}$.

Initial screenings were carried out to determine $\mathrm{IC}_{50}$ values for newly synthesized compounds tested on CML (KU812 and K562) and AML (MV4-11) cell lines (Table 1).
Compounds $\mathbf{7 c}, \mathbf{7} c^{\prime}$ and $\mathbf{1 3} d, 13 d^{\prime}$ substituted respectively in position 7 and 8 on the THQ ring were less effective in inhibiting leukemic cell growth than $17 \mathrm{f}$. In addition, results clearly indicated that substitution by the 2-pyridinyl group in each position on the THQ ring (analogs $9 a-c$ ) dramatically reduced the effectiveness of $17 \mathrm{f}$. Precursor compounds $\mathbf{6 a - c}$, $8 \mathrm{~b}, \mathrm{c}$ and 10 showed average $I C_{50}$ values similar or higher than $17 f$ on both CML and $A M L$ cell lines. In sharp contrast, compounds $7 \mathrm{a}$ and $7 \mathrm{a}^{\prime}$ substituted in position 5 on THQ ring respectively by the 3- and 4-pyridinyl moieties showed similar or enhanced antileukemic activity when compared to $\mathbf{1 7 f}$. Thereby, activity of compounds $7 \mathrm{a}, \mathbf{7} \mathrm{a}^{\prime}$ and $\mathbf{1 7 f}$ seems to be promoted by their pyridinyl nitrogen similar position (i.e., possible formation of a hydrogen bond in a same area). This observation can explain also the lower activity of compound $\mathbf{7} \mathbf{b}^{\prime}$, where pyridinyl nitrogen is slightly offset from this area. To confirm these results in other leukemic cells, $I C_{50}$ values of $7 \mathrm{a}$ and were also determined in KCL-22 (CML), KG1a and MOLM13 (AML) cell lines. Excepted for KG1a cells, $I_{50}$ values obtained for $7 a$ and $7 a^{\prime}$ were nearly close to those obtained for $\mathbf{1 7 f}$ (Table 2). Besides, compounds $6 \mathrm{c}, 10,13 \mathrm{~d}$ and $13 \mathrm{~d}$ ', which only showed a good activity on MV4-11 cells, were also evaluated on KG1a and MOLM-13 cell lines but did not exhibit relevant results (Supplementary data). Additionally, cytotoxicity effects of $7 a$ and $7 a^{\prime}$ were also determined on human bone marrow stromal cells (cell line: HS-27a and primary mesenchymal stem cells: MSC) which play a crucial role in the leukemic niche. Results showed that cytotoxic effects of $7 a$ and $7 a^{\prime}$ on

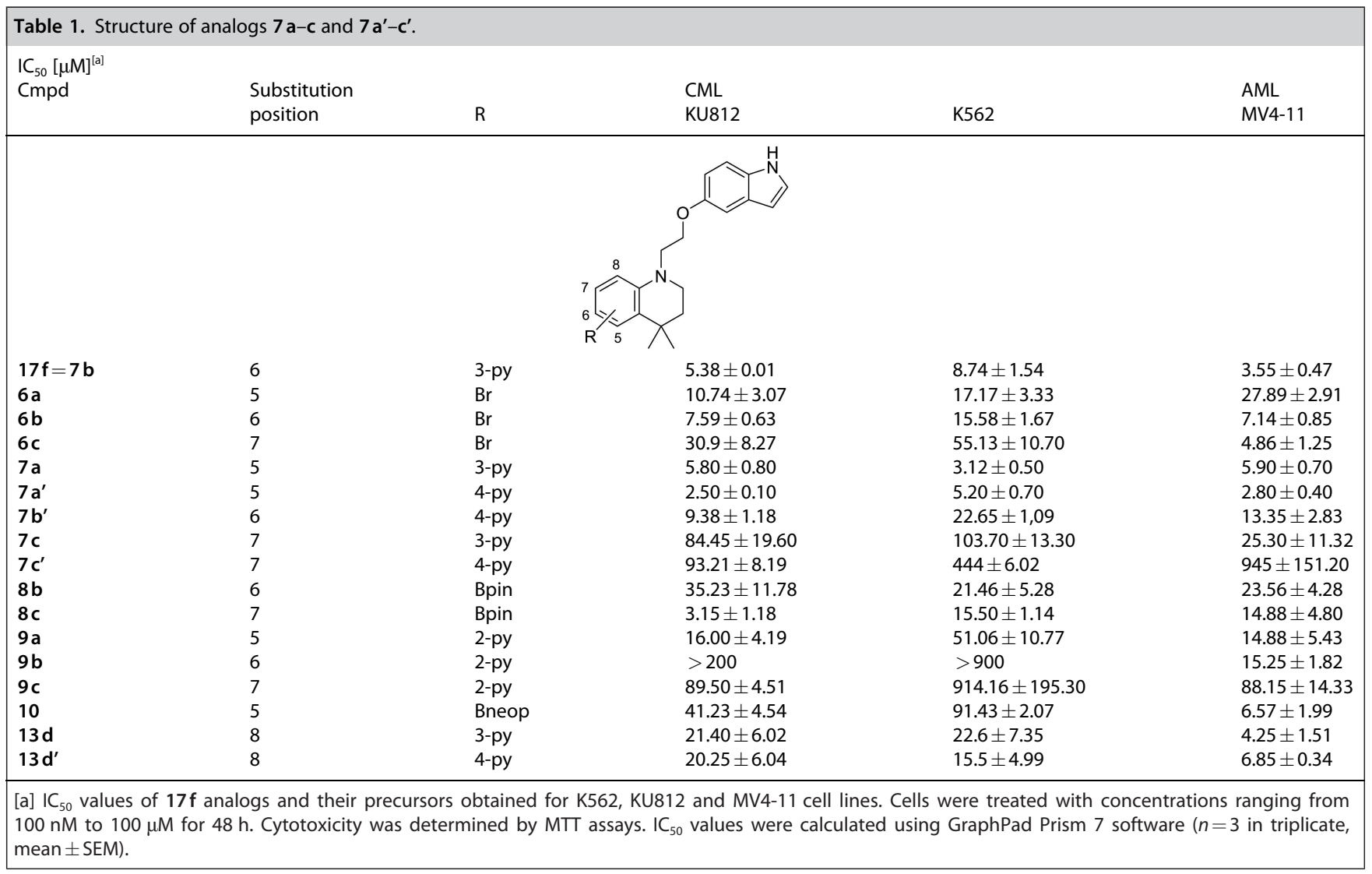




\begin{tabular}{|c|c|c|c|c|c|}
\hline \multirow[b]{3}{*}{ Cmpd } & \multicolumn{2}{|c|}{$\mathrm{IC} 50[\mu \mathrm{M}]^{[\mathrm{b}]}$} & & \multirow{2}{*}{\multicolumn{2}{|c|}{ 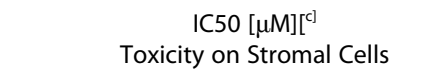 }} \\
\hline & CML & \multicolumn{2}{|c|}{ AML } & & \\
\hline & KCL-22 & KG1a & MOLM-13 & HS-27a & MSC \\
\hline $17 \mathrm{f}$ & $5.6 \pm 0.8$ & $3.4 \pm 0.9$ & $3.3 \pm 1.0$ & $63.7 \pm 0.1$ & $33.6 \pm 5.9$ \\
\hline $7 a$ & $6.9 \pm 3.1$ & $7.8 \pm 0.9$ & $5.4 \pm 0.5$ & $27.0 \pm 1.4$ & $27.1 \pm 1.4$ \\
\hline $7 a^{\prime}$ & $8.7 \pm 1.9$ & $6.9 \pm 0.8$ & $4.7 \pm 1.0$ & $23.2 \pm 5.0$ & $12.5 \pm 0.5$ \\
\hline
\end{tabular}

[a] Cells were treated with concentrations ranging from $100 \mathrm{nM}$ to $100 \mu \mathrm{M}$ for $48 \mathrm{~h}$ and cytotoxicity was determined by $\mathrm{MTT}$ assays. IC $\mathrm{C}_{50}$ values were

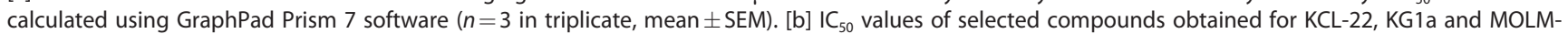
13 cell lines. [c] $\mathrm{IC}_{50}$ values of selected compounds obtained for HS-27a and MSC stromal cells.
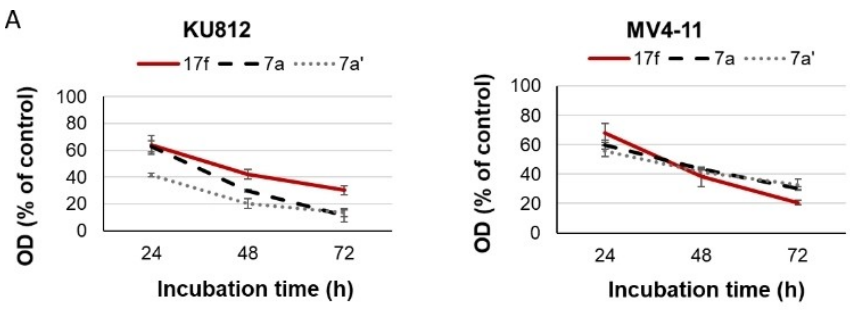

B KU812
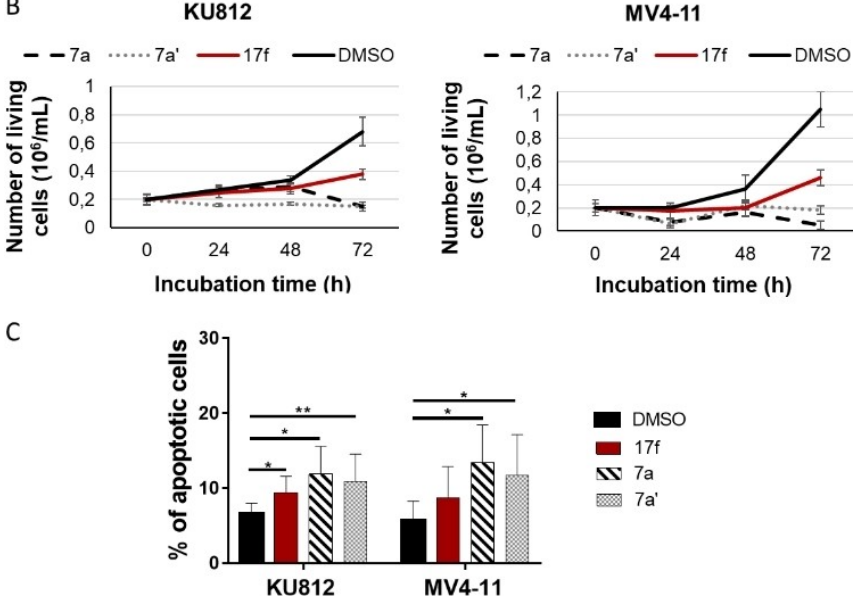

Figure 2. A) Viability kinetics of KU812 and MV4-11 treated with compounds $17 \mathrm{f}, 7 \mathrm{a}$ and $7 \mathrm{a}^{\prime}$. Cells were treated with $5 \mu \mathrm{M}$ of inhibitors or with DMSO as control for 24, 48 or $72 \mathrm{~h}$. Cytotoxic effect was determined by MTT assays. Results are presented as percentage of control. Values were calculated by using GraphPad Prism 7 software ( $n=3$ in triplicate, mean \pm SEM). B) Growth kinetics of KU812 (up) and MV4-11 (down) treated with $5 \mu \mathrm{M}$ of compounds 17f, $7 \mathrm{a}$ and $\mathbf{7} \mathrm{a}^{\prime}$ or DMSO as control determined by Trypan blue exclusion assays ( $n=3$ in triplicate, mean \pm SEM). C) Representative flow cytometry histogram of KU812 and MV4-11 cells treated with $3 \mu \mathrm{M}$ of $7 \mathrm{a}, \mathbf{7} \mathrm{a}^{\prime}$ and $\mathbf{1 7 f}$ or DMSO. Cells were stained with FITC Annexin V and 7-AAD, and the percentage of apoptotic cells was then evaluated by flow cytometry $(n=3$ in triplicate; mean \pm SEM).

HS-27a and MSC were slightly higher than those observed for $17 \mathrm{f}$ but $I C_{50}$ values remained five to ten times higher than those required to inhibit leukemic cell growth (Table 2).

To analyze the growth inhibitory properties of $7 a$ and $7 a^{\prime}$, KU812 and MV4-11 cells were treated or not (DMSO as control) with $5 \mu \mathrm{M}$ (concentration that roughly corresponds to that of the $17 \mathrm{f} \mathrm{IC} C_{50}$ values) of $7 \mathrm{a}, 7 \mathrm{a}^{\prime}$ and $\mathbf{1 7} \mathrm{f}$ during $72 \mathrm{~h}$. Cell viability and the number of living cells were daily determined by MTT and trypan blue dye exclusion assays respectively. Results showed that $\mathbf{7} \mathrm{a}$ and $\mathbf{7} \mathrm{a}^{\prime}$, when compared to $\mathbf{1 7 f}$, have a slightly higher or similar cytotoxic effect in KU812 and MV4-11 cells
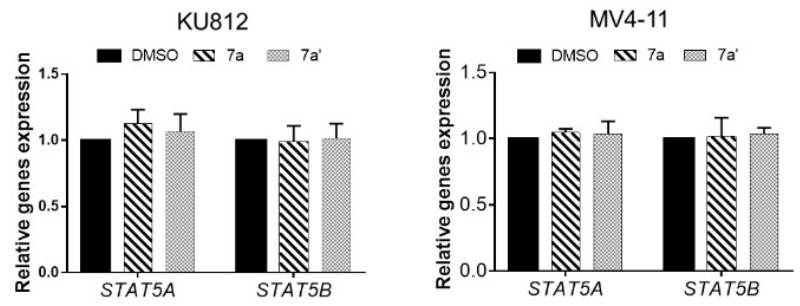

B

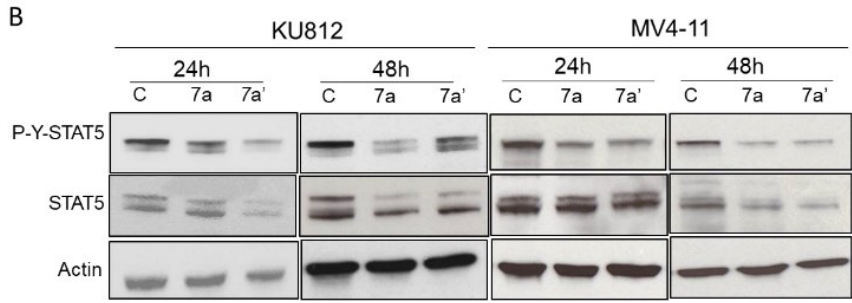

Figure 3. A) qRT-PCR analysis of STAT5A and STAT5B transcripts in KU812 and MV4-11 cells treated or not with $7 \mathrm{a}, 7 \mathrm{a}^{\prime}$ or DMSO as control for $24 \mathrm{~h}$. Results are presented as the fold changes in gene expression in treated cells normalized to internal control genes (GAPDH, ACTB, RPL13a) and relative to control cells (normalized to $1 ; n=3$ in triplicate; mean $\pm S E M$ ). B) Protein extracts from KU812, MV4-11 cells treated with 7a and $7 a^{\prime}(3 \mu M)$ or DMSO $(-)$ for $48 \mathrm{~h}$ were analyzed by western blotting to detect P-Y-STAT5 and STAT5 protein expression. Actin was used as a loading control $(n=3)$.

respectively (Figure $2 \mathrm{~A}$ ). Both compounds have also similar or enhanced growth inhibitory properties (Figure $2 \mathrm{~B}$ ) and were able to induce apoptosis in both leukemic cell lines (Figure $2 \mathrm{C}$ ).

We previously demonstrated that $\mathbf{1 7} \mathrm{f}$ inhibits STAT5 signaling in CML and AML cells, we then addressed whether $7 a$ and $7 a^{\prime}$ also suppress STAT5 activity and expression in KU812 and MV4-11 cells. A concentration of $3 \mu \mathrm{M}$ was used in the experiments to keep close to the $\mathrm{IC}_{50}$ values of both compounds. We first evaluated impact of $7 a$ and $7 a^{\prime}$ on STAT5A and STAT5B gene expression in both leukemic cell lines by qRT-PCR experiments. Results showed that $7 a$ and $7 a^{\prime}$ had no effect on STAT5A and STAT5B mRNA levels in leukemic cells treated for $15 \mathrm{~h}$ with these compounds (Figure $3 \mathrm{~A}$ ). We then analyzed the phosphorylation and expression of STAT5 in KU812 and MV4-11 cells exposed to $7 \mathrm{a}$ and $7 \mathrm{a}^{\prime}(3 \mu \mathrm{M})$ for 24 and $48 \mathrm{~h}$. Results showed that both compounds inhibited the phosphorylation of STAT5 and reduced STAT5 protein expression at $48 \mathrm{~h}$ posttreatment suggesting that $7 \mathrm{a}$ and $\mathbf{7 a}$ as $\mathbf{1 7 f}$ might indirectly interfere with the stability/degradation of the proteins (Fig- 
ure $3 B){ }^{[42]}$ Further investigations are then required to determine impact of these molecules on the ubiquitin/proteasome system.

We then addressed whether $7 a$ and $7 a^{\prime}$ inhibited STAT5 transcriptional activity. qRT-PCR experiments were conducted to determine effects of these compounds on STAT5-dependent expression of target genes such as PIM1 and CISH in KU812 and MV4-11 cells. $17 \mathrm{f}$ was used as a positive control in these experiments. We found that both molecules were as efficient as $17 \mathrm{f}$ to downregulate PIM1 and CISH gene expression (Figure 4).

We previously showed that $17 \mathrm{f}$ overcomes the resistance of CML and AML cells to IM and Ara-C. ${ }^{[42]}$ We then ask whether $7 \mathrm{a}$ and $\mathbf{7} a^{\prime}$ had a greater impact than $\mathbf{1 7 f}$ to overcome the resistance of CML cells to IM. K562R cells that were previously used as an IM-resistant leukemic cell model, were treated with various concentrations of $17 f, 7 a$ and $7 a^{\prime}$ (ranging from 0.1 to $10 \mu \mathrm{M})$ in combination with $1 \mu \mathrm{M} \mathrm{IM}$. Results showed that compound 7a' exhibited a slightly but significant better cytotoxic effect than $17 \mathrm{f}$ and $7 \mathrm{a}$ at 1 and $5 \mu \mathrm{M}$ concentrations (Figure 5A). This was also confirmed in kinetic experiments using $5 \mu \mathrm{M}$ as the difference in the optimal concentration between each compound (Figure 5B).
KU812

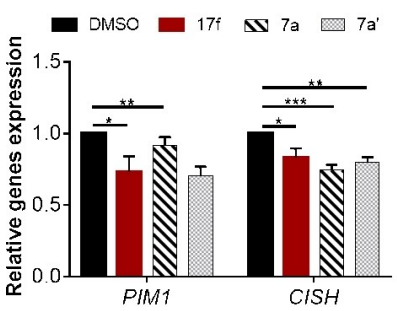

MV4-11

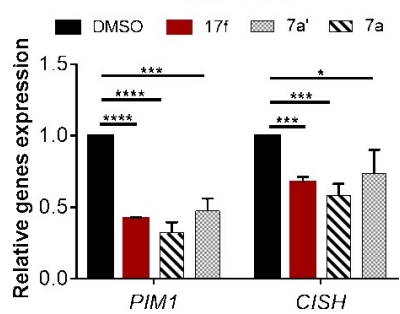

Figure 4. qRT-PCR analysis of STAT5 target genes, PIM1 and CISH transcripts, in KU812 and MV4-11 cells treated or not with $7 a, 7 a^{\prime}, 17 f(3 \mu \mathrm{M})$ or DMSO as the control for $24 \mathrm{~h}$. Results are presented as the fold changes in gene expression in treated cells normalized to internal control genes (GAPDH, $A C T B, R P L 13 a$ ) and relative to control cells (normalized to $1 ; n=3$ in triplicate; mean \pm SEM).
A

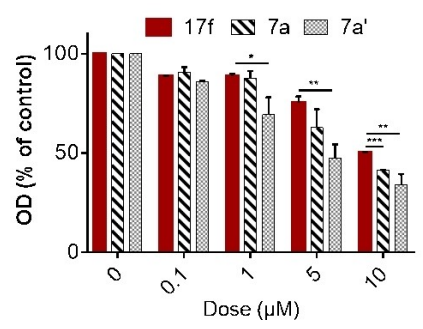

B

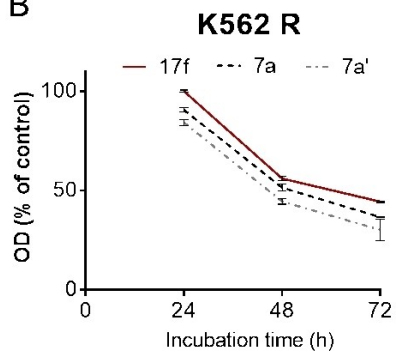

Figure 5. A) Metabolic activity of IM-resistant cells K562 R treated with IM $(1 \mu \mathrm{M})$ in combination with ranging doses from $100 \mathrm{nM}$ to $10 \mu \mathrm{M}$ of $7 \mathrm{a}, 7 \mathrm{a}$ or $\mathbf{1 7 f}$, for $48 \mathrm{~h}$. Cytotoxic effect was determined by MTT assays. Results are presented as percentage of control. Values were calculated by using GraphPad Prism 7 software ( $n=3$ in triplicate, mean \pm SEM). B) Viability kinetics of IM-resistant cells K562 R treated with IM (1 $\mu \mathrm{M})$ as control in combination with selected compound, $17 \mathrm{f}, 7 \mathrm{a}$ or $7 \mathrm{a}^{\prime}(5 \mu \mathrm{M})$ for 24,48 or $72 \mathrm{~h}$. The cytotoxic effect was determined by MTT assays. Results are presented as percentage of control. Values were calculated by using GraphPad Prism 7 software ( $n=3$ in triplicate; mean \pm SEM).

\section{Conclusion}

In summary, among the ten new analogs of $17 \mathrm{f}$, compounds $7 \mathrm{a}$ and $7 \mathrm{a}^{\prime}$ were found to be the most interesting inhibitors of STAT5 signaling and myeloid leukemia cell growth when compared to $17 \mathrm{f}$. Our SAR studies demonstrated that both positions of pyridinyl moiety on the THQ aromatic part and its nitrogen position were essential in the antileukemic properties of $7 a$ and $7 a^{\prime}$. Indeed, the C-5 tetrahydroquinoline 3- and 4pyridinyl substitutions in $7 \mathrm{a}$ and $7 \mathrm{a}^{\prime}$, gave better $\mathrm{IC}_{50}$ results than C-7 and C-8 THQ ring substitutions as well as all 2-pyridinyl substituted derivatives.

This work also showed that, as $\mathbf{1 7} \mathrm{f}$, both $7 \mathrm{a}$ and $7 \mathrm{a}^{\text {' block }}$ STAT5 transcriptional activity by affecting not only the phosphorylation but also expression of the proteins. Experiments are now conducted to determine whether both compounds can affect expression of STAT5A, STAT5B and most importantly the oncogenic STAT5B ${ }^{\mathrm{N} 642 \mathrm{H}}$ mutant which is frequently expressed in different $T$ cell leukemias/lymphomas and in T cell lymphoblastic leukemia. ${ }^{[45,46]}$ SAR studies will be then continued on our compound central scaffold. In particular substitutions in positions C- 5 and C- 6 of the THQ ring by polynitrogen aromatic heterocycles like pyrimidine or pyrazine will be conducted to generate molecules with improved antileukemic potential while avoiding their cytotoxic effects on normal cells. This should help us to get a better understanding of the influence of nitrogen on the THQ part of our structure.

\section{Experimental Section}

\section{Chemistry}

\section{Materials and methods}

Reagents and solvents were purchased from commercial sources (Acros, Aldrich and VWR international) and were used without further purification. For synthesis in anhydrous and inert conditions, the glassware was dried with a heat gun during several vacuum-dry argon cycles and maintained under argon. Reactions were monitored by using thin-layer chromatography (TLC), pre-coated aluminum sheets silica gel 60 F254 marketed by Merck and visualized under UV fluorescence 254 and $365 \mathrm{~nm}$. Purifications were carried out by chromatography on silica gel columns on an ISCO purification unit, Combi Flash RF 75 PSI, with Redisep flash silica gel columns (60 ̊̊, 230-400 mesh, grade 9385). Melting points (mp) were determined on a Büchi melting point apparatus Model B-540 in open capillaries. NMR spectra were recorded at $300 \mathrm{MHz}\left({ }^{1} \mathrm{H}\right)$ or $75 \mathrm{MHz}\left({ }^{13} \mathrm{C}\right)$ on a Bruker AVANCE AV 300 instrument. All NMR experiments were realized in deuterated chloroform $\left(\mathrm{CDCl}_{3}\right)$ or dimethylsulfoxide $\left(\left[\mathrm{D}_{6}\right] \mathrm{DMSO}\right)$. Chemical shifts were reported in parts per million (ppm; $\delta$ relative to residual solvent peak for ${ }^{1} \mathrm{H}$ and ${ }^{13} \mathrm{C}$ ) and coupling constants $(J)$ are reported in hertz [Hz]. The notations used are: s: singlet; d: doublet; dd: doublet of doublet; t: triplet; m: multiplet; br: broad signal. High-resolution mass spectra (HRMS) was performed by the mass spectrometry service on a QExactive spectrometer from Thermo Scientific using the electrospray ionization (ESI) technique. If necessary, the purity was determined by high performance liquid chromatography (HPLC). Purity of all final compounds was $95 \%$ or higher. HPLC analyses were carried out with a LaChrom Elite system [Hitachi L-2130 
(pump), L-2200 (autosampler) and L-2400 (UV-detector)] using $254 \mathrm{~nm}$ UV for detection. The column was a XBridge C-18 (250x $10 \mathrm{~mm}, 4 \mu \mathrm{m}, 135 \AA$ A); elution was performed with $0.1 \%$ (by volume) of TFA in water (solvent $A$ ), and $0.1 \%$ of TFA in acetonitrile (solvent B); gradient $20-100 \%$ of $B$ over 35 minutes with a flow rate of $1 \mathrm{~mL} \cdot \mathrm{min}^{-1}$; column temperature of $25^{\circ} \mathrm{C}$; injection of $10 \mu \mathrm{L}$ in DMSO.

\section{Method A: Nucleophilic substitution $(1 a, 1 b)$}

To a solution of bromoaniline (1.0 equiv) in dry pyridine at $0^{\circ} \mathrm{C}$ under argon, was added dropwise 3,3-dimethylacryloylchloride (1.2 equiv). The reaction mixture was stirred for $5 \mathrm{~h}$ at RT and then carefully poured into an Erlenmeyer flask containing $1 \mathrm{M} \mathrm{HCl}$ under magnetic stirring. The product was filtered, washed by water and heptane, then purified by flash chromatography on silica gel.

\section{N-(2-Bromophenyl)-3-methylbut-2-enamide (1 a)}

Following method $A$, the reaction of 2-bromoaniline $(4.60 \mathrm{~mL}$, $40.70 \mathrm{mmol}), 3,3$-dimethylacryloyl chloride $(5.50 \mathrm{~mL}, 48.84 \mathrm{mmol})$ in dry pyridine $(17.70 \mathrm{~mL})$ afforded, after purification by flash chromatography on silica gel (cyclohexane/ethyl acetate 70:30), the title compound $1 \mathrm{a}$ as a white solid (10.30 g, quant.); m.p. $100^{\circ} \mathrm{C} .{ }^{1} \mathrm{H}$ NMR $\left(300 \mathrm{MHz},\left[\mathrm{D}_{6}\right] \mathrm{DMSO}\right): \delta=9.28(\mathrm{~s}, 1 \mathrm{H}), 7.68-7.58(\mathrm{~m}$ $2 \mathrm{H}), 7.40-7.30(\mathrm{~m}, 1 \mathrm{H}), 7.15-7.07(\mathrm{~m}, 1 \mathrm{H}), 6.05-5.96(\mathrm{~m}, 1 \mathrm{H}), 2.13(\mathrm{~d}$, $J=1.1 \mathrm{~Hz}, 3 \mathrm{H}), 1.86(\mathrm{~d}, J=1.0 \mathrm{~Hz}, 3 \mathrm{H}) .{ }^{13} \mathrm{C}$ NMR $\left(75 \mathrm{MHz},\left[\mathrm{D}_{6}\right] \mathrm{DMSO}\right):$ $\delta=164.6,152.1,136.5,132.6,127.8,127.1,126.7,118.6,117.9,27.0$, 19.6. HRMS-ESI $(\mathrm{m} / \mathrm{z})$ calcd for $\mathrm{C}_{11} \mathrm{H}_{13}{ }^{79} \mathrm{BrNO}^{+}: 254.01750[\mathrm{M}+\mathrm{H}]^{+}$, found: 254.01704 ; calcd for $\mathrm{C}_{11} \mathrm{H}_{13}{ }^{81} \mathrm{BrNO}^{+} 256.01546[\mathrm{M}+\mathrm{H}]^{+}$, found: 256.01461.

\section{N-(3-Bromophenyl)-3-methylbut-2-enamide (1 b)}

Following method $A$, the reaction of 3-bromoaniline $(11.40 \mathrm{~mL}$, $105.00 \mathrm{mmol})$, 3,3-dimethylacryloyl chloride $(14.00 \mathrm{~mL}$, $126.00 \mathrm{mmol})$ in dry pyridine $(46.00 \mathrm{~mL})$ afforded, after purification by flash chromatography on silica gel (cyclohexane/ethyl acetate $70: 30$ ), the title compound $1 \mathrm{~b}$ as a white solid ( $26.70 \mathrm{~g}$, quant.); m.p. $115^{\circ} \mathrm{C} .{ }^{1} \mathrm{H}$ NMR $\left(300 \mathrm{MHz},\left[\mathrm{D}_{6}\right] \mathrm{DMSO}\right): \delta=10.01(\mathrm{~s}, 1 \mathrm{H}), 8.02$ (dd, $J=1.8,1.8 \mathrm{~Hz}, 1 \mathrm{H}), 7.48$ (ddd, $J=7.8,1.8,1.8 \mathrm{~Hz}, 1 \mathrm{H}), 7.25$ (dd, $J=7.8,7.8 \mathrm{~Hz}, 1 \mathrm{H}$ ), 7.19 (ddd, $J=7.8,1.8,1.8 \mathrm{~Hz}, 1 \mathrm{H}), 5.84(\mathrm{dq}, J=$ $1.1,1.1 \mathrm{~Hz}, 1 \mathrm{H}), 2.15(\mathrm{~d}, J=1.1 \mathrm{~Hz}, 3 \mathrm{H}), 1.87(\mathrm{~d}, J=1.1 \mathrm{~Hz}, 3 \mathrm{H}) .{ }^{13} \mathrm{C}$ NMR $\left(75 \mathrm{MHz},\left[\mathrm{D}_{6}\right] \mathrm{DMSO}\right): \delta=164.8,152.4,141.2,130.7,125.4$, 121.5, 121.2, 118.8, 117.7, 27.1, 19.6. HRMS-ESI $(\mathrm{m} / \mathrm{z})$ calcd for $\mathrm{C}_{11} \mathrm{H}_{13}{ }^{79} \mathrm{BrNO}^{+}$: $254.01750[\mathrm{M}+\mathrm{H}]^{+}$, found: 254.01729 ; calcd for $\mathrm{C}_{11} \mathrm{H}_{13}{ }^{81} \mathrm{BrNO}^{+}: 256.01546[\mathrm{M}+\mathrm{H}]^{+}$, found: 256.01488 .

\section{Method B: Cyclization (2a, 2c, 2d)}

To a solution of $\mathrm{N}$-bromophenyl-3-methylbut-2-enamide 1 (1.0 equiv) in dry dichloromethane at $0^{\circ} \mathrm{C}$ under argon was added portionwise aluminium chloride ( 4.0 equiv) over $30 \mathrm{~min}$. The reaction mixture was stirred for $1 \mathrm{~h}$ at $\mathrm{RT}$, then poured on ice and extracted with diethyl ether. After extraction, the combined organic extracts were washed with saturated aqueous $\mathrm{NaHCO}_{3}$ solution, brine and then dried with $\mathrm{MgSO}_{4}$. After evaporation under reduced pressure, the crude product was purified by flash chromatography on silica gel.
5-Bromo-4,4-dimethyl-3,4-dihydroquinolin-2(1H)-one (2 a) and 7-bromo-4,4-dimethyl-3,4-dihydroquinolin-2(1H)-one (2c)

Following method $\mathrm{B}$, the reaction of $\mathrm{N}$-(3-bromophenyl)-3-methylbut-2-enamide $1 \mathrm{~b}(20.00 \mathrm{~g} ; 78.70 \mathrm{mmol})$ and aluminium chloride $(42.00 \mathrm{~g}, 314.80 \mathrm{mmol})$ in dry dichloromethane $(97 \mathrm{~mL})$ afforded, after purification by flash chromatography on silica gel (cyclohexane/ethyl acetate 70:30), the title compounds $2 \mathrm{a}$ as a white solid (7.38 g, 43\%) and $2 \mathrm{c}$ as a white solid (9.05 g, 47\%).

2 a: m.p. $137^{\circ} \mathrm{C}$. ${ }^{1} \mathrm{H}$ NMR $\left(300 \mathrm{MHz},\left[\mathrm{D}_{6}\right] \mathrm{DMSO}\right): \delta=10.28$ (brs, $\left.1 \mathrm{H}\right)$, 7.20 (dd, $J=7.9,1.3 \mathrm{~Hz}, 1 \mathrm{H}), 7.04(\mathrm{~d}, J=7.9,7.9 \mathrm{~Hz}, 1 \mathrm{H}), 6.88(\mathrm{dd}, J=$ $7.9,1.3 \mathrm{~Hz}, 1 \mathrm{H}), 2.43(\mathrm{~s}, 2 \mathrm{H}), 1.44(\mathrm{~s}, 6 \mathrm{H}) .{ }^{13} \mathrm{C} \mathrm{NMR}\left(75 \mathrm{MHz},\left[\mathrm{D}_{6}\right]\right.$ DMSO): $\delta=168.4,139.8,130.0,128.9,128.6,120.7,115.8,46.8,36.5$, 27.0 (2 C). HRMS-ESI $(\mathrm{m} / \mathrm{z})$ calcd for $\mathrm{C}_{11} \mathrm{H}_{13}{ }^{79} \mathrm{BrNO}^{+}: 254.01750[\mathrm{M}+$ $\mathrm{H}]^{+}$, found: 254.01728; calcd for $\mathrm{C}_{11} \mathrm{H}_{13}{ }^{81} \mathrm{BrNO}^{+}: 256.01546 ;[\mathrm{M}+\mathrm{H}]^{+}$ found: 256.01501.

2 c: m.p. $175^{\circ} \mathrm{C} .{ }^{1} \mathrm{H}$ NMR (300 MHz, [D ${ }$ DMSO) $\delta 10.25$ (brs, 1H), 7.23 $(\mathrm{d}, J=8.3 \mathrm{~Hz}, 1 \mathrm{H}), 7.13(\mathrm{dd}, J=8.3,2.0 \mathrm{~Hz}, 1 \mathrm{H}), 7.03(\mathrm{~d}, J=2.0 \mathrm{~Hz}$ $1 \mathrm{H}), 2.36(\mathrm{~s}, 2 \mathrm{H}), 1.20(\mathrm{~s}, 6 \mathrm{H}) .{ }^{13} \mathrm{C}$ NMR $\left(75 \mathrm{MHz},\left[\mathrm{D}_{6}\right] \mathrm{DMSO}\right) \delta 169.4$, $138.7,131.5,126.5,124.8,119.5,117.6,44.5,33.4,27.0$ (2 C). HRMSESI $(\mathrm{m} / \mathrm{z})$ calcd for $\mathrm{C}_{11} \mathrm{H}_{13}{ }^{79} \mathrm{BrNO}^{+}$: $254.01750[\mathrm{M}+\mathrm{H}]^{+}$, found: 254.01706; calcd for $\mathrm{C}_{11} \mathrm{H}_{13}{ }^{81} \mathrm{BrNO}^{+}$: $256.01546[\mathrm{M}+\mathrm{H}]^{+}$, found: 256.01466

\section{8-Bromo-4,4-dimethyl-3,4-dihydroquinolin-2(1H)-one (2d)}

Following method $\mathbf{B}$, the reaction of $\mathrm{N}$-(2-bromophenyl)-3-methylbut-2-enamide 1 a $(20.00 \mathrm{~g} ; 78.70 \mathrm{mmol})$ and aluminium chloride $(42.00 \mathrm{~g}, 314.80 \mathrm{mmol})$ in dry dichloromethane $(97 \mathrm{~mL})$ afforded, after purification by flash chromatography on silica gel (cyclohexane/ethyl acetate 70:30), the title compound $\mathbf{2} \mathbf{d}$ as a white solid $(18.85 \mathrm{~g}, 94 \%)$; m.p. $108^{\circ} \mathrm{C} .{ }^{1} \mathrm{H}$ NMR $\left(300 \mathrm{MHz},\left[\mathrm{D}_{6}\right]\right.$ DMSO): $\delta=9.17(\mathrm{~s}, 1 \mathrm{H}), 7.46$ (dd, $J=7.8,1.2 \mathrm{~Hz}, 1 \mathrm{H}), 7.33$ (dd, $J=$ $7.8,1.2 \mathrm{~Hz}, 1 \mathrm{H}), 6.96(\mathrm{dd}, J=7.8,7.8 \mathrm{~Hz}, 1 \mathrm{H}), 2.41(\mathrm{~s}, 2 \mathrm{H}), 1.24(\mathrm{~s}$, $6 \mathrm{H}) .{ }^{13} \mathrm{C}$ NMR (75 MHz, $\left[\mathrm{D}_{6}\right.$ ]DMSO): $\delta=169.4,135.5,134.7,130.9$, 124.1, 123.9, 109.7, 44.6, 34.3, 26.9 (2 C). HRMS-ESI $(\mathrm{m} / \mathrm{z})$ calcd for $\mathrm{C}_{11} \mathrm{H}_{13}{ }^{79} \mathrm{BrNO}^{+}:$254.01750 $[\mathrm{M}+\mathrm{H}]^{+}$, found: 254.01710 , calcd for $\mathrm{C}_{11} \mathrm{H}_{13}{ }^{81} \mathrm{BrNO}^{+}: 256.01546[\mathrm{M}+\mathrm{H}]^{+}$, found: 256.01492 .

\section{Method C: Reduction (3a, 3c, 3d)}

To a solution of bromo-4,4-dimethyl-3,4-dihydroquinolin-2(1H)-one 2 (1.0 equiv) in dry toluene at $0^{\circ} \mathrm{C}$ under argon was added dropwise a solution of $\mathrm{BH}_{3}$. THF $1 \mathrm{M}$ (2.5 equiv). The reaction mixture was refluxed for $4 \mathrm{~h}$ and then quenched at $0^{\circ} \mathrm{C}$ by the addition of saturated aqueous $\mathrm{NaHCO}_{3}$ solution. After extraction with ethyl acetate, the combined organic extracts were washed with brine and dried with $\mathrm{MgSO}_{4}$. After evaporation under reduced pressure, the crude product was purified by flash chromatography on silica gel.

\section{5-Bromo-4,4-dimethyl-1,2,3,4-tetrahydroquinoline (3a)}

Following method $\mathrm{C}$, the reaction of 5-bromo-4,4-dimethyl-3,4dihydroquinolin-2(1H)-one $2 \mathrm{a}(3.00 \mathrm{~g} ; 11.80 \mathrm{mmol})$ and $\mathrm{BH}_{3} \cdot \mathrm{THF}$ $1 \mathrm{M}(30.00 \mathrm{~mL}, 29.51 \mathrm{mmol})$ in dry toluene $(28 \mathrm{~mL})$ afforded, after purification by flash chromatography on silica gel (cyclohexane/ ethyl acetate $80: 20$ ), the title compound $3 \mathrm{a}$ as a light yellow oil (2.28 g, $81 \%$ ). ${ }^{1} \mathrm{H}$ NMR $\left(300 \mathrm{MHz}, \mathrm{CDCl}_{3}\right): \delta=6.91$ (dd, $J=7.8,1.4 \mathrm{~Hz}$, $1 \mathrm{H}), 6.75(\mathrm{dd}, J=8.0,7.8 \mathrm{~Hz}, 1 \mathrm{H}), 6.45(\mathrm{dd}, J=8.0,1.4 \mathrm{~Hz}, 1 \mathrm{H}), 3.78$ (brs, 1H), 3.24-3.16 (m, 2H), 1.85-1.78 (m, 2H), 1.57 (s, 6H). ${ }^{13} \mathrm{C} N M R$ $\left(75 \mathrm{MHz}, \mathrm{CDCl}_{3}\right): \delta=146.7,128.1,127.6,124.7,124.1,114.9,41.9$, 38.0, 33.9, 28.7 (2 C). HRMS-ESI $(\mathrm{m} / \mathrm{z})$ calcd for $\mathrm{C}_{11} \mathrm{H}_{15}{ }^{79} \mathrm{BrN}^{+}$: 
240.03797 $[\mathrm{M}+\mathrm{H}]^{+}$, found: 240.03824; calcd for $\mathrm{C}_{11} \mathrm{H}_{15}{ }^{81} \mathrm{BrN}^{+}$ $242.03619[\mathrm{M}+\mathrm{H}]^{+}$, found: 242.03542 .

\section{7-Bromo-4,4-dimethyl-1,2,3,4-tetrahydroquinoline (3c)}

Following method $C$, the reaction of 7-bromo-4,4-dimethyl-3,4dihydroquinolin-2(1H)-one $2 \mathrm{c}(7.00 \mathrm{~g} ; 27.50 \mathrm{mmol})$ and $\mathrm{BH}_{3} \cdot \mathrm{THF}$ $1 \mathrm{M}(70.00 \mathrm{~mL}, 69.00 \mathrm{mmol})$ in dry toluene $(65 \mathrm{~mL})$ afforded, after purification by flash chromatography on silica gel (cyclohexane/ ethyl acetate $80: 20$ ), the title compound $3 c$ as a light yellow oil $(5.95 \mathrm{~g}, 90 \%) .{ }^{1} \mathrm{H}$ NMR $\left(300 \mathrm{MHz}, \mathrm{CDCl}_{3}\right): \delta=7.03(\mathrm{~d}, J=8.2 \mathrm{~Hz}, 1 \mathrm{H})$, $6.74(\mathrm{dd}, J=8.2,2.1 \mathrm{~Hz}, 1 \mathrm{H}), 6.62(\mathrm{~d}, J=2.1 \mathrm{~Hz}, 1 \mathrm{H}), 3.87(\mathrm{brs}, 1 \mathrm{H})$, $3.34-3.28(\mathrm{~m}, 2 \mathrm{H}), 1.75-1.69(\mathrm{~m}, 2 \mathrm{H}), 1.27(\mathrm{~s}, 6 \mathrm{H}) .{ }^{13} \mathrm{C}$ NMR $(75 \mathrm{MHz}$, $\left.\mathrm{CDCl}_{3}\right): \delta=144.8,129.3,128.0,120.0,119.9,116.6,38.4,36.8,31.7$, 30.8 (2 C). HRMS-ESI $(\mathrm{m} / \mathrm{z})$ calcd for $\mathrm{C}_{11} \mathrm{H}_{15}{ }^{79} \mathrm{BrN}^{+}: 240.03824[\mathrm{M}+$ $\mathrm{H}]^{+}$, found: 240.03807 ; calcd for $\mathrm{C}_{11} \mathrm{H}_{15}{ }^{81} \mathrm{BrN}^{+}: 242.03619[\mathrm{M}+\mathrm{H}]^{+}$ found: 242.03541 .

\section{8-Bromo-4,4-dimethyl-1,2,3,4-tetrahydroquinoline (3d)}

Following method $\mathrm{C}$, the reaction of 8-bromo-4,4-dimethyl-3,4dihydroquinolin-2(1H)-one $2 \mathbf{d}(10.00 \mathrm{~g} ; 39.30 \mathrm{mmol})$ and $\mathrm{BH}_{3} \cdot \mathrm{THF}$ $1 \mathrm{M}(100.00 \mathrm{~mL}, 98.20 \mathrm{mmol})$ in dry toluene $(92 \mathrm{~mL})$ afforded, after purification by flash chromatography on silica gel (cyclohexane/ ethyl acetate $80: 20$ ), the title compound $3 \mathrm{~d}$ as a light yellow oil (8.96 g, $76 \%)$. ${ }^{1} \mathrm{H}$ NMR $\left(300 \mathrm{MHz}, \mathrm{CDCl}_{3}\right): \delta=7.26$ (dd, $J=7.9,1.4 \mathrm{~Hz}$, $1 \mathrm{H}), 7.17(\mathrm{dd}, J=7.7,1.4 \mathrm{~Hz}, 1 \mathrm{H}), 6.53(\mathrm{dd}, J=7.9,7.7 \mathrm{~Hz}, 1 \mathrm{H}), 4.69$ (brs, 1H), 3.49-3.36 (m, 2H), 1.83-1.71 (m, 2H), 1.32 (s, 6H). ${ }^{13} \mathrm{C}$ NMR $\left(75 \mathrm{MHz}, \mathrm{CDCl}_{3}\right): \delta=140.5,132.0,130.1,125.4,117.2,109.0,38.5$, 36.7, 32.4, 30.9 (2 C). HRMS-ESI $(\mathrm{m} / \mathrm{z})$ calcd for $\mathrm{C}_{11} \mathrm{H}_{15}{ }^{79} \mathrm{BrN}^{+}$: $240.03824[\mathrm{M}+\mathrm{H}]^{+}$, found: 240.03775; calcd for $\mathrm{C}_{11} \mathrm{H}_{15}{ }^{81} \mathrm{BrN}^{+}$: $242.03619[\mathrm{M}+\mathrm{H}]^{+}$, found: 242.03521 .

\section{Method D: Reductive amination (5a, 5c, $12 a, 12 b)$}

To a solution of 2-((1-benzyl-1H-indol-5-yl)oxy)ethanol 4 (1.0 equiv) in dry 1,2-DCE under argon, was added 2-iodoxybenzoic acid (IBX; 3.0 equiv). The resulting mixture was stirred $2 \mathrm{~h}$ at $80^{\circ} \mathrm{C}$ and then cooled to RT. The reaction medium was filtered through a sintered glass funnel over a round bottom flask containing the corresponding amine (2.1 equiv) in dry 1,2-DCE. The resulting mixture was stirred for $15 \mathrm{~min}$, and then $\mathrm{NaBH}(\mathrm{OAC})_{3}$ (2.0 equiv) was added. The reaction medium was stirred $2 \mathrm{~h}$ at RT and then hydrolyzed with a saturated aqueous $\mathrm{NaHCO}_{3}$ solution. After extraction with ethyl acetate, the combined organic extracts were washed with brine and dried with $\mathrm{MgSO}_{4}$. After evaporation under reduced pressure, the crude product was purified by flash chromatography on silica gel.

\section{1-(2-((1-Benzyl-1H-indol-5-yl)oxy)ethyl)-5-bromo-4,4-dimethyl- 1,2,3,4-tetrahydroquinoline (5a)}

Following method $\mathrm{D}$, the reaction of 2-((1-benzyl-1H-indol-5-yl)oxy) ethanol $4(0.35 \mathrm{~g}, 1.32 \mathrm{mmol})$, IBX (1.11 g, $3.96 \mathrm{mmol})$, 5-bromo-4,4dimethyl-1,2,3,4-tetrahydroquinoline 3 a $(0.66 \mathrm{~g}, 2.77 \mathrm{mmol}), \mathrm{NaBH}$ $(\mathrm{OAc})_{3}(0.56 \mathrm{~g}, 2.64 \mathrm{mmol})$ in dry 1,2-DCE $(5 \mathrm{~mL})$ afforded, after purification by flash chromatography on silica gel (cyclohexane/ ethyl acetate $80: 20$ ), a mixture of title compound 5 a with starting material $3 \mathrm{a}$. The mixture was dissolved in diethyl ether $(200 \mathrm{~mL})$, washed by $\mathrm{HCl} 3 \mathrm{M}(3 \times 100 \mathrm{~mL})$ and brine $(1 \times 100 \mathrm{~mL})$, dried with $\mathrm{MgSO}_{4}$ and evaporated under reduced pressure to give $5 \mathrm{a}$ as a light yellow oil $(0.51 \mathrm{~g}, 78 \%)$. ${ }^{1} \mathrm{H}$ NMR $\left(300 \mathrm{MHz},\left[\mathrm{D}_{6}\right] \mathrm{DMSO}\right): \delta=$ $7.44(\mathrm{~d}, J=3.1 \mathrm{~Hz}, 1 \mathrm{H}), 7.33-7.20(\mathrm{~m}, 4 \mathrm{H}), 7.17-7.12(\mathrm{~m}, 2 \mathrm{H}), 7.04(\mathrm{~d}$, $J=2.3 \mathrm{~Hz}, 1 \mathrm{H}), 6.88-6.69(\mathrm{~m}, 4 \mathrm{H}), 6.35(\mathrm{~d}, J=3.1 \mathrm{~Hz}, 1 \mathrm{H}), 5.36(\mathrm{~s}, 2 \mathrm{H})$, $4.10(\mathrm{t}, J=5.7 \mathrm{~Hz}, 2 \mathrm{H}), 3.68(\mathrm{t}, J=5.7 \mathrm{~Hz}, 2 \mathrm{H}), 3.34-3.29(\mathrm{~m}, 2 \mathrm{H})$, $1.77-1.68(\mathrm{~m}, 2 \mathrm{H}), 1.46(\mathrm{~s}, 6 \mathrm{H}) .{ }^{13} \mathrm{C}$ NMR $\left(75 \mathrm{MHz},\left[\mathrm{D}_{6}\right] \mathrm{DMSO}\right): \delta=$ 153.0, 147.5, 138.8, 131.6, 130.1, 129.2, 128.9 (2 C), 128.3, 128.2, $127.7,127.3$ (2C), 123.6, 122.8, 112.0, 111.9, 111.3, 103.7, 101.0, 65.5, 51.9, 49.7, 46.0, 41.3, 34.1, 28.8 (2 C). HRMS-ESI ( $\mathrm{m} / \mathrm{z})$ calcd for $\mathrm{C}_{28} \mathrm{H}_{30}{ }^{79} \mathrm{BrN}^{+}$: $489.15360[\mathrm{M}+\mathrm{H}]^{+}$, found: 489.15329; calcd for $\mathrm{C}_{28} \mathrm{H}_{30}{ }^{81} \mathrm{BrN}^{+}: 491.15156[\mathrm{M}+\mathrm{H}]^{+}$, found: 491.15117.

\section{1-(2-((1-Benzyl-1H-indol-5-yl)oxy)ethyl)-7-bromo-4,4-dimethyl- 1,2,3,4-tetrahydroquinoline $(5 \mathrm{C})$}

Following method $\mathrm{D}$, the reaction of 2-((1-benzyl-1H-indol-5-yl)oxy) ethanol $4(0.50 \mathrm{~g}, 1.87 \mathrm{mmol})$, IBX (1.57 g, $5.61 \mathrm{mmol})$, 7-bromo-4,4dimethyl-1,2,3,4-tetrahydroquinoline $3 \mathrm{c}(0.95 \mathrm{~g}, 3.92 \mathrm{mmol}), \mathrm{NaBH}$ $(\mathrm{OAC})_{3}(0.80 \mathrm{~g}, 3.74 \mathrm{mmol})$ in dry 1,2-DCE $(7 \mathrm{~mL})$ afforded, after purification by flash chromatography on silica gel (cyclohexane/ ethyl acetate 98:2), a mixture of title compound $5 \mathrm{c}$ with starting material $3 c$. The mixture was dissolved in diethyl ether $(200 \mathrm{~mL})$, washed by $\mathrm{HCl} 3 \mathrm{M}(3 \times 100 \mathrm{~mL})$ and brine $(1 \times 100 \mathrm{~mL})$, dried with $\mathrm{MgSO}_{4}$ and evaporated under reduced pressure to give $5 \mathrm{c}$ as a light yellow oil $(0.45 \mathrm{~g}, 49 \%) .{ }^{1} \mathrm{H}$ NMR $\left(300 \mathrm{MHz},\left[\mathrm{D}_{6}\right] \mathrm{DMSO}\right): \delta=$ $7.44(\mathrm{~d}, J=3.1 \mathrm{~Hz}, 1 \mathrm{H}), 7.34-7.21(\mathrm{~m}, 4 \mathrm{H}), 7.17-7.12(\mathrm{~m}, 2 \mathrm{H}), 7.06(\mathrm{~d}$, $J=2.4 \mathrm{~Hz}, 1 \mathrm{H}), 7.04(\mathrm{~d}, J=8.2 \mathrm{~Hz}, 1 \mathrm{H}), 6.80(\mathrm{~d}, J=1.9 \mathrm{~Hz}, 1 \mathrm{H}), 6.71$ (dd, $J=8.9,2.4 \mathrm{~Hz}, 1 \mathrm{H}), 6.62(\mathrm{dd}, J=8.2,1.9 \mathrm{~Hz}, 1 \mathrm{H}), 6.36(\mathrm{~d}, J=$ $3.1 \mathrm{~Hz}, 1 \mathrm{H}), 5.36(\mathrm{~s}, 2 \mathrm{H}), 4.12(\mathrm{t}, J=5.4 \mathrm{~Hz}, 2 \mathrm{H}), 3.67(\mathrm{t}, J=5.4 \mathrm{~Hz}$, $2 \mathrm{H}), 3.45-3.39(\mathrm{~m}, 2 \mathrm{H}), 1.66-1.60(\mathrm{~m}, 2 \mathrm{H}), 1.17(\mathrm{~s}, 6 \mathrm{H}) .{ }^{13} \mathrm{C} N M R$ $\left(75 \mathrm{MHz},\left[\mathrm{D}_{6}\right.\right.$ ]DMSO): $\delta=152.5,145.2,138.4,131.1,129.8,129.7$, 128.7, 128.5 (2 C), 127.4, 127.3, 126.9 (2C), 119.8, 117.4, 112.6, $111.5,110.9,103.2,100.6,65.1,50.1,49.2,45.9,35.9,31.4,30.0$ (2 C).

HRMS-ESI $(\mathrm{m} / \mathrm{z})$ calcd for $\mathrm{C}_{28} \mathrm{H}_{30}{ }^{79} \mathrm{BrN}^{+}: 489.15360[\mathrm{M}+\mathrm{H}]^{+}$, found: 489.15317; calcd for $\mathrm{C}_{28} \mathrm{H}_{30}{ }^{81} \mathrm{BrN}^{+}$: $491.15156[\mathrm{M}+\mathrm{H}]^{+}$, found: 491.15109 .

\section{Method E: Heterocyclic amine debenzylation ( $\left.6 a, 6 c, 13 d-d^{\prime}\right)$}

To a solution of the benzyl indole 5 or 12 (1.0 equiv) in DMSO at RT was added $t$ BuOK ( 14.0 equiv). Dry air was then bubbled into the solution and stirred $2 \mathrm{~h}$ at RT. The reaction mixture was quenched with saturated aqueous $\mathrm{NH}_{4} \mathrm{Cl}$ solution, extracted with ethyl acetate, washed with brine and dried with $\mathrm{MgSO}_{4}$. After evaporation under reduced pressure, the crude product was purified by flash chromatography on silica gel.

\section{1-(2-((1H-Indol-5-yl)oxy)ethyl)-5-bromo-4,4-dimethyl- 1,2,3,4-tetrahydroquinoline (6a)}

Following method $E$, the reaction of 1-(2-((1-benzyl-1H-indol-5-yl) oxy)ethyl)-5-bromo-4,4-dimethyl-1,2,3,4-tetrahydroquinoline $\quad 5$ a $(2.02 \mathrm{~g} ; 4.13 \mathrm{mmol})$ and tBuOK $(6.50 \mathrm{~g}, 57.78 \mathrm{mmol})$ in DMSO $(122.50 \mathrm{~mL})$ afforded, after purification by flash chromatography on silica gel (cyclohexane/ethyl acetate 80:20), the title compound 6 a as a light yellow oil $(1.61 \mathrm{~g}, 98 \%)$. HPLC purity: $98.8 \%, t_{\mathrm{R}}=$ 30.06 min. ${ }^{1} \mathrm{H}$ NMR (300 MHz, $\left[\mathrm{D}_{6}\right] \mathrm{DMSO}$ ): $\delta=10.91$ (brs, $1 \mathrm{H}$ ), 7.28$7.23(\mathrm{~m}, 2 \mathrm{H}), 7.02(\mathrm{~d}, J=2.4 \mathrm{~Hz}, 1 \mathrm{H}), 6.89-6.82(\mathrm{~m}, 1 \mathrm{H}), 6.79-6.67(\mathrm{~m}$ $3 \mathrm{H}), 6.32-6.27(\mathrm{~m}, 1 \mathrm{H}), 4.11(\mathrm{t}, J=5.7 \mathrm{~Hz}, 2 \mathrm{H}), 3.69(\mathrm{t}, J=5.7 \mathrm{~Hz}, 2 \mathrm{H})$, $3.36-3.29(\mathrm{~m}, 2 \mathrm{H}), 1.78-1.71(\mathrm{~m}, 2 \mathrm{H}), 1.48(\mathrm{~s}, 6 \mathrm{H}) .{ }^{13} \mathrm{C}$ NMR $(75 \mathrm{MHz}$ [D $\mathrm{D}_{6}$ DMSO): $\delta=152.3,147.1,131.1,128.0,127.9,127.7,125.8,123.2$, $122.3,112.0,111.5,111.4,102.7,100.8,65.0,51.5,45.6,40.8,33.6$, 28.4 (2 C). HRMS-ESI $(\mathrm{m} / \mathrm{z})$ calcd for $\mathrm{C}_{21} \mathrm{H}_{24}{ }^{70} \mathrm{BrN}_{2} \mathrm{O}^{+}: 399.10665[\mathrm{M}+$ $\mathrm{H}]^{+}$, found: 399.10623, calcd for $\mathrm{C}_{21} \mathrm{H}_{24}{ }^{81} \mathrm{BrN}_{2} \mathrm{O}^{+}$: $401.10461[\mathrm{M}+$ $\mathrm{H}^{+}$, found: 401.10407 . 
1-(2-((1H-Indol-5-yl)oxy)ethyl)-7-bromo-4,4-dimethyl1,2,3,4-tetrahydroquinoline (6c)

Following method $\mathrm{E}$, the reaction of 1-(2-((1-benzyl-1H-indol-5-yl) oxy)ethyl)-5-bromo-4,4-dimethyl-1,2,3,4-tetrahydroquinoline $5 \mathrm{c}$ $(1.00 \mathrm{~g} ; 2.04 \mathrm{mmol})$ and tBuOK $(3.21 \mathrm{~g}, 28.60 \mathrm{mmol})$ in DMSO $(60 \mathrm{~mL})$ afforded, after purification by flash chromatography on silica gel (cyclohexane/ethyl acetate $80: 20$ ), the title compound $6 \mathrm{c}$ as a yellow oil $(0.60 \mathrm{~g}, 74 \%)$. HPLC purity: $99.4 \%, t_{\mathrm{R}}=29.57 \mathrm{~min} .{ }^{1} \mathrm{H}$ NMR (300 MHz, [D $\mathrm{D}_{6}$ DMSO): $\delta=10.92(\mathrm{brs}, 1 \mathrm{H}), 7.31-7.23(\mathrm{~m}, 2 \mathrm{H})$, 7.09-7.01 (m, 2H), $6.82(\mathrm{~d}, J=2.0 \mathrm{~Hz}, 1 \mathrm{H}), 6.70(\mathrm{dd}, J=8.7,2.4 \mathrm{~Hz}$, $1 \mathrm{H}), 6.63(\mathrm{dd}, J=8.2,2.0 \mathrm{~Hz}, 1 \mathrm{H}), 6.32-6.27(\mathrm{~m}, 1 \mathrm{H}), 4.13(\mathrm{t}, J=$ $5.5 \mathrm{~Hz}, 2 \mathrm{H}), 3.68(\mathrm{t}, J=5.5 \mathrm{~Hz}, 2 \mathrm{H}), 3.48-3.40(\mathrm{~m}, 2 \mathrm{H}), 1.68-1.60(\mathrm{~m}$, $2 \mathrm{H}), 1.18(\mathrm{~s}, 6 \mathrm{H}) .{ }^{13} \mathrm{C}$ NMR $\left(75 \mathrm{MHz},\left[\mathrm{D}_{6}\right.\right.$ ]DMSO): $\delta=152.3,145.2$, $131.1,129.8,128.0,127.4,125.8,119.9,117.4,112.7,112.0,111.4$ 102.7, 100.8, 65.1, 50.1, 45.9, 35.9, 31.4, 30.0 (2 C). HRMS-ESI (m/z) calcd for $\mathrm{C}_{21} \mathrm{H}_{24}{ }^{79} \mathrm{BrN}_{2} \mathrm{O}^{+}$: $399.10665[\mathrm{M}+\mathrm{H}]^{+}$, found: 399.10635, calcd for $\mathrm{C}_{21} \mathrm{H}_{24}{ }^{81} \mathrm{BrN}_{2} \mathrm{O}^{+}: 401.10461[\mathrm{M}+\mathrm{H}]^{+}$, found: 401.10420 .

\section{Method F: Suzuki coupling (7a-a', 7c-c', $\left.11 d-d^{\prime}\right)$}

A mixture of the corresponding aryl bromide 6 (1.0 equiv), $\mathrm{K}_{2} \mathrm{CO}_{3}$ (1.5 equiv) and the corresponding boronic acid (3.0 equiv) in DMF and water was degassed with argon. $\mathrm{PdCl}_{2}\left(\mathrm{PPh}_{3}\right)_{2}$ (0.1 equiv) was then added and the resulting mixture was stirred $5 \mathrm{~h}$ at $90^{\circ} \mathrm{C}$. The mixture was cooled to RT, filtered through a pad of dicalite and extracted with ethyl acetate. Combined organic extracts were washed with brine and dried with $\mathrm{MgSO}_{4}$. After evaporation under reduced pressure, the crude product was purified by flash chromatography on silica gel.

\section{1-(2-((1H-Indol-5-yl)oxy)ethyl)-4,4-dimethyl-5-(pyridin-3-yl)- 1,2,3,4-tetrahydroquinoline (7a)}

Following method $\mathrm{F}$, the reaction of 1-(2-((1H-indol-5-yl)oxy)ethyl)5-bromo-4,4-dimethyl-1,2,3,4-tetrahydroquinoline 6 a $\quad$ (75 mg, $0.19 \mathrm{mmol})$, pyridin-3-ylboronic acid $(69 \mathrm{mg}, 0.56 \mathrm{mmol}), \mathrm{K}_{2} \mathrm{CO}_{3}$ $(78 \mathrm{mg}, 0.56 \mathrm{mmol})$ and $\mathrm{PdCl}_{2}\left(\mathrm{PPh}_{3}\right)_{2}(13 \mathrm{mg}, 0.02 \mathrm{mmol})$ in $\mathrm{DMF}$ $(4.50 \mathrm{~mL})$ and water $(0.90 \mathrm{~mL})$ afforded, after purification by flash chromatography on silica gel (cyclohexane/ethyl acetate 70:30), the title compound $7 \mathrm{a}$ as a yellow oil $(30 \mathrm{mg}, 40 \%)$. HPLC purity: $97.9 \%, t_{\mathrm{R}}=16.57 \mathrm{~min} .{ }^{1} \mathrm{H}$ NMR $\left(300 \mathrm{MHz},\left[\mathrm{D}_{6}\right] \mathrm{DMSO}\right): \delta=10.93$ (brs, $1 \mathrm{H}), 8.52(\mathrm{dd}, J=4.8,1.7 \mathrm{~Hz}, 1 \mathrm{H}), 8.42(\mathrm{~d}, J=1.7 \mathrm{~Hz}, 1 \mathrm{H}), 7.63(\mathrm{ddd}$, $J=7.8,1.7,1.7 \mathrm{~Hz}, 1 \mathrm{H}), 7.38(\mathrm{dd}, J=7.8,4.8 \mathrm{~Hz}, 1 \mathrm{H}), 7.31-7.25(\mathrm{~m}$, $2 \mathrm{H}), 7.06(\mathrm{~d}, J=2.4 \mathrm{~Hz}, 1 \mathrm{H}), 6.99(\mathrm{dd}, J=8.5,7.3 \mathrm{~Hz}, 1 \mathrm{H}), 6.78(\mathrm{dd}$, $J=8.5,1.3 \mathrm{~Hz}, 1 \mathrm{H}), 6.74(\mathrm{dd}, J=8.7,2.4 \mathrm{~Hz}, 1 \mathrm{H}), 6.34-6.28(\mathrm{~m}, 1 \mathrm{H})$, $6.13(\mathrm{dd}, J=7.3,1.3 \mathrm{~Hz}, 1 \mathrm{H}), 4.18(\mathrm{t}, J=5.6 \mathrm{~Hz}, 2 \mathrm{H}), 3.75(\mathrm{t}, J=$ $5.6 \mathrm{~Hz}, 2 \mathrm{H}), 3.47(\mathrm{t}, J=6.0 \mathrm{~Hz}, 2 \mathrm{H}), 1.62-1.53(\mathrm{~m}, 2 \mathrm{H}), 0.90(\mathrm{~s}, 6 \mathrm{H}) .{ }^{13} \mathrm{C}$ NMR $\left(75 \mathrm{MHz},\left[\mathrm{D}_{6}\right] \mathrm{DMSO}\right): \delta=152.4,149.3,147.5,144.5,140.9$, $138.4,136.4,131.1,128.2,128.0,126.0,125.8,122.5,119.5,112.0$, $111.5,111.3,102.7,100.8,65.0,51.0,45.7,39.3,32.9,30.9,30.7$. HRMS-ESI $(\mathrm{m} / \mathrm{z})$ calcd for $\mathrm{C}_{26} \mathrm{H}_{27} \mathrm{~N}_{3} \mathrm{O}^{+}: 398.22269[\mathrm{M}+\mathrm{H}]^{+}$, found: 398.21964.

\section{1-(2-((1H-Indol-5-yl)oxy)ethyl)-4,4-dimethyl-5-(pyridin-4-yl)- 1,2,3,4-tetrahydroquinoline ( $\left.7 a^{\prime}\right)$}

Following method $\mathrm{F}$, the reaction of 1-(2-((1H-indol-5-yl)oxy)ethyl)5-bromo-4,4-dimethyl-1,2,3,4-tetrahydroquinoline 6 a $\quad(80 \mathrm{mg}$, $0.20 \mathrm{mmol})$, pyridin-4-ylboronic acid $(74 \mathrm{mg}, 0.60 \mathrm{mmol}), \mathrm{K}_{2} \mathrm{CO}_{3}$ ( $83 \mathrm{mg}, 0.60 \mathrm{mmol})$ and $\mathrm{PdCl}_{2}\left(\mathrm{PPh}_{3}\right)_{2}(14 \mathrm{mg}, 0.02 \mathrm{mmol})$ in DMF $(4.00 \mathrm{~mL})$ and water $(0.80 \mathrm{~mL})$ afforded, after purification by flash chromatography on silica gel (cyclohexane/ethyl acetate 70:30), the title compound $7 \mathrm{a}^{\prime}$ as a yellow solid $(41 \mathrm{mg}, 51 \%) ;$ m.p. $180^{\circ} \mathrm{C}$. HPLC purity: $99.8 \%, t_{\mathrm{R}}=16.65 \mathrm{~min} .{ }^{1} \mathrm{H}$ NMR (300 MHz, $\left.\left[\mathrm{D}_{6}\right] \mathrm{DMSO}\right)$ : $\delta=10.92($ brs, $1 \mathrm{H}), 8.53(\mathrm{~d}, J=4.9 \mathrm{~Hz}, 2 \mathrm{H}), 7.31-7.24(\mathrm{~m}, 4 \mathrm{H}), 7.05$ $(\mathrm{d}, J=2.4 \mathrm{~Hz}, 1 \mathrm{H}), 6.98(\mathrm{dd}, J=8.4,7.3 \mathrm{~Hz}, 1 \mathrm{H}), 6.80-6.76(\mathrm{~m}, 1 \mathrm{H})$ $6.73(\mathrm{dd}, J=8.7,2.4 \mathrm{~Hz}, 1 \mathrm{H}), 6.33-6.29(\mathrm{~m}, 1 \mathrm{H}), 6.06(\mathrm{dd}, J=7.3$, $0.9 \mathrm{~Hz}, 1 \mathrm{H}), 4.18(\mathrm{t}, J=5.6 \mathrm{~Hz}, 2 \mathrm{H}), 3.75(\mathrm{t}, J=5.6 \mathrm{~Hz}, 2 \mathrm{H}), 3.51-3.43$ $(\mathrm{m}, 2 \mathrm{H}), 1.62-1.54(\mathrm{~m}, 2 \mathrm{H}), 0.95(\mathrm{~s}, 6 \mathrm{H}) .{ }^{13} \mathrm{C} \mathrm{NMR}\left(75 \mathrm{MHz},\left[\mathrm{D}_{6}\right]\right.$ DMSO): $\delta=152.4,148.6$ (2 C), 144.4, 142.5, 139.5, 131.1, 128.0 (2 C), 126.0, 125.8, $124.8(2 \mathrm{C}), 118.4,112.0,111.5,111.2,102.7,100.8$, $65.0,50.9,45.7,39.0,32.9,30.6(2 \mathrm{C})$. HRMS-ESI $(\mathrm{m} / \mathrm{z})$ calcd for $\mathrm{C}_{26} \mathrm{H}_{28} \mathrm{~N}_{3} \mathrm{O}^{+}: 398.22269[\mathrm{M}+\mathrm{H}]^{+}$, found: 398.21954 .

\section{1-(2-((1H-Indol-5-yl)oxy)ethyl)-4,4-dimethyl-7-(pyridin-3-yl)- 1,2,3,4-tetrahydroquinoline ( $7 c$ )}

Following method $\mathrm{F}$, the reaction of 1-(2-((1H-indol-5-yl)oxy)ethyl)7-bromo-4,4-dimethyl-1,2,3,4-tetrahydroquinoline $6 \mathrm{c} \quad(100 \mathrm{mg}$ $0.25 \mathrm{mmol}$ ), pyridin-3-ylboronic acid $(92 \mathrm{mg}, 0.75 \mathrm{mmol}), \mathrm{K}_{2} \mathrm{CO}_{3}$ $(104 \mathrm{mg}, 0.75 \mathrm{mmol})$ and $\mathrm{PdCl}_{2}\left(\mathrm{PPh}_{3}\right)_{2}(17 \mathrm{mg}, 0.025 \mathrm{mmol})$ in DMF $(5.00 \mathrm{~mL})$ and water $(1.20 \mathrm{~mL})$ afforded, after purification by flash chromatography on silica gel (cyclohexane/ethyl acetate 60:40), the title compound $7 \mathrm{c}$ as a yellow solid $(60 \mathrm{mg}, 61 \%) ;$ m.p. $209^{\circ} \mathrm{C}$. HPLC purity: $99.4 \%, t_{R}=18.14 \mathrm{~min} .{ }^{1} \mathrm{H}$ NMR $(300 \mathrm{MHz}$, [D 6 ]DMSO): $\delta=10.90(\mathrm{brs}, 1 \mathrm{H}), 8.84(\mathrm{~d}, J=1.9 \mathrm{~Hz}, 1 \mathrm{H}), 8.52(\mathrm{dd}, J=4.8,1.3 \mathrm{~Hz}$, $1 \mathrm{H}), 7.99-7.94(\mathrm{~m}, 1 \mathrm{H}), 7.42(\mathrm{dd}, J=7.9,4.8 \mathrm{~Hz}, 1 \mathrm{H}), 7.28-7.21(\mathrm{~m}$ 3H), $7.06(\mathrm{~d}, J=2.4 \mathrm{~Hz}, 1 \mathrm{H}), 6.91(\mathrm{~d}, J=1.5 \mathrm{~Hz}, 1 \mathrm{H}), 6.82(\mathrm{dd}, J=7.8$, $1.5 \mathrm{~Hz}, 1 \mathrm{H}), 6.70(\mathrm{dd}, J=8.7,2.4 \mathrm{~Hz}, 1 \mathrm{H}), 6.31-6.25(\mathrm{~m}, 1 \mathrm{H}), 4.20(\mathrm{t}$, $J=5.6 \mathrm{~Hz}, 2 \mathrm{H}), 3.80(\mathrm{t}, J=5.6 \mathrm{~Hz}, 2 \mathrm{H}), 3.52-3.45(\mathrm{~m}, 2 \mathrm{H}), 1.75-1.66$ $(\mathrm{m}, 2 \mathrm{H}), 1.25$ (s, 6H). ${ }^{13} \mathrm{C}$ NMR (75 MHz, [D 6 ]DMSO): $\delta=152.3,147.6$, $147.3,144.1,136.7,135.4,134.3,131.1,130.7,128.0,126.5,125.8$, $123.8,113.9,112.0,111.5,109.0,102.7,100.8,65.2,50.2,46.0,36.4$ 31.5, 30.4 (2 C). HRMS-ESI $(\mathrm{m} / \mathrm{z})$ calcd for $\mathrm{C}_{26} \mathrm{H}_{27} \mathrm{~N}_{3} \mathrm{O}^{+}: 398.22269[\mathrm{M}$ $+\mathrm{H}]^{+}$, found: 398.21970 .

\section{1-(2-((1H-Indol-5-yl)oxy)ethyl)-4,4-dimethyl-7-(pyridin-4-yl)- 1,2,3,4-tetrahydroquinoline $\left(7 c^{\prime}\right)$}

Following method $\mathrm{F}$, the reaction of 1-(2-((1H-indol-5-yl)oxy)ethyl)7-bromo-4,4-dimethyl-1,2,3,4-tetrahydroquinoline 6c (100 mg, $0.25 \mathrm{mmol}$ ), pyridin-4-ylboronic acid $(92 \mathrm{mg}, 0.75 \mathrm{mmol}), \mathrm{K}_{2} \mathrm{CO}_{3}$ $(104 \mathrm{mg}, 0.75 \mathrm{mmol})$ and $\mathrm{PdCl}_{2}\left(\mathrm{PPh}_{3}\right)_{2}(17 \mathrm{mg}, 0.025 \mathrm{mmol})$ in DMF $(5 \mathrm{~mL})$ and water $(1 \mathrm{~mL})$ afforded, after purification by flash chromatography on silica gel (cyclohexane/ethyl acetate 60:40), the title compound $7 \mathrm{c}^{\prime}$ as a white solid $(58.70 \mathrm{mg}, 59 \%)$; $\mathrm{mp}$ : $209^{\circ} \mathrm{C}$. HPLC purity: $99.9 \%, t_{\mathrm{R}}=18.31 \mathrm{~min} .{ }^{1} \mathrm{H}$ NMR $\left(300 \mathrm{MHz},\left[\mathrm{D}_{6}\right]\right.$ DMSO): $\delta=10.92$ (brs, $1 \mathrm{H}), 8.53-8.48(\mathrm{~m}, 2 \mathrm{H}), 7.56-7.51(\mathrm{~m}, 2 \mathrm{H})$, 7.30-7.22 (m, 3H), $7.07(\mathrm{~d}, J=2.3 \mathrm{~Hz}, 1 \mathrm{H}), 6.95(\mathrm{~d}, J=1.5 \mathrm{~Hz}, 1 \mathrm{H})$, 6.89 (dd, $J=7.9,1.5 \mathrm{~Hz}, 1 \mathrm{H}), 6.71(\mathrm{dd}, J=8.7,2.3 \mathrm{~Hz}, 1 \mathrm{H}), 6.31-6.26$ $(\mathrm{m}, 1 \mathrm{H}), 4.21(\mathrm{t}, J=5.5 \mathrm{~Hz}, 2 \mathrm{H}), 3.80(\mathrm{t}, J=5.5 \mathrm{~Hz}, 2 \mathrm{H}), 3.52-3.44(\mathrm{~m}$, $2 \mathrm{H}), 1.74-1.68(\mathrm{~m}, 1 \mathrm{H}), 1.25(\mathrm{~s}, 6 \mathrm{H}) .^{13} \mathrm{C}$ NMR $\left(75 \mathrm{MHz},\left[\mathrm{D}_{6}\right] \mathrm{DMSO}\right): \delta=$ $152.3,149.9$ (2 C), 148.0, 144.2, 135.6, 131.8, 131.1, 128.0, 126.5, $125.8,121.1$ (2 C), 113.7, 112.0, 111.5, 108.7, 102.8, 100.8, 65.2, 50.1 45.9, 36.3, 31.6, 30.3 (2 C). HRMS-ESI (m/z) calcd for $\mathrm{C}_{26} \mathrm{H}_{27} \mathrm{~N}_{3} \mathrm{O}^{+}$: 398.22269 $[\mathrm{M}+\mathrm{H}]^{+}$, found: 398.21947 .

\section{Method G: Boronate formation (8a-c, 10)}

A mixture of the corresponding aryl bromide 6 (1.0 equiv), KOAc (5.0 equiv) and the corresponding bisdiboron (1.2 equiv) in dioxane was degassed with argon. Then $\mathrm{PdCl}_{2}(\mathrm{dppf})$ ( 0.07 equiv) was added and the resulting mixture was stirred at $100^{\circ} \mathrm{C}$ for $12 \mathrm{~h}$. The mixture was cooled to RT, filtered through a pad of dicalite, washed with water and extracted with ethyl acetate. Combined organic extracts were washed with brine and dried with $\mathrm{MgSO}_{4}$. After evaporation under reduced pressure, the crude product was purified by flash chromatography on silica gel. 
1-(2-((1H-Indol-5-yl)oxy)ethyl)-4,4-dimethyl-

5-(4,4,5,5-tetramethyl-1,3,2-dioxaborolan-2-yl)1,2,3,4-tetrahydroquinoline (8a)

Following method $\mathrm{G}$, the reaction of 1-(2-((1H-indol-5-yl)oxy)ethyl)5-bromo-4,4-dimethyl-1,2,3,4-tetrahydroquinoline 6 a $\quad$ (335 mg, $0.84 \mathrm{mmol}$ ), bis(pinacolato)diboron $(256 \mathrm{mg}, 1.01 \mathrm{mmol}), \mathrm{KOAc}$ $(412 \mathrm{mg}, 4.20 \mathrm{mmol})$ and $\mathrm{PdCl}_{2}(\mathrm{dppf})(43 \mathrm{mg}, 0.059 \mathrm{mmol})$ in dioxane $(5 \mathrm{~mL})$ afforded, after purification by flash chromatography on silica gel (cyclohexane/ethyl acetate $80: 20$ ), the title compound $8 \mathrm{a}$ as a light yellow solid (188 mg, $50 \%$ ).

\section{1-(2-((1H-Indol-5-yl)oxy)ethyl)-4,4-dimethyl- \\ 6-(4,4,5,5-tetramethyl-1,3,2-dioxaborolan-2-yl)- 1,2,3,4-tetrahydroquinoline (8b)}

Following method $\mathrm{G}$, the reaction of 1-(2-((1H-indol-5-yl)oxy)ethyl)6-bromo-4,4-dimethyl-1,2,3,4-tetrahydroquinoline 6b $\quad(660 \mathrm{mg}$, $1.65 \mathrm{mmol})$, bis(pinacolato)diboron $(504 \mathrm{mg}, 1.98 \mathrm{mmol}), \mathrm{KOAC}$ $(811 \mathrm{mg}, 8.26 \mathrm{mmol})$ and $\mathrm{PdCl}_{2}(\mathrm{dppf})(84.7 \mathrm{mg}, 0.116 \mathrm{mmol})$ in dioxane $(8.3 \mathrm{~mL})$ afforded, after purification by flash chromatography on silica gel (cyclohexane/ethyl acetate $80: 20$ ), the title compound $8 \mathrm{~b}$ as a beige solid (468 mg, $63 \%$ ); m.p. : $201^{\circ} \mathrm{C}$. HPLC purity: $95.2 \%, t_{\mathrm{R}}=29.52 \mathrm{~min} .{ }^{1} \mathrm{H}$ NMR $\left(300 \mathrm{MHz},\left[\mathrm{D}_{6}\right] \mathrm{DMSO}\right): \delta=$ $10.91(\mathrm{~s}, 1 \mathrm{H}), 7.40(\mathrm{~d}, J=1.5 \mathrm{~Hz}, 1 \mathrm{H}), 7.32-7.22(\mathrm{~m}, 3 \mathrm{H}), 7.02(\mathrm{~d}, J=$ $2.3 \mathrm{~Hz}, 1 \mathrm{H}), 6.73-6.64(\mathrm{~m}, 2 \mathrm{H}), 6.31-6.27(\mathrm{~m}, 1 \mathrm{H}), 4.14(\mathrm{t}, J=5.5 \mathrm{~Hz}$, $2 \mathrm{H}), 3.72(\mathrm{t}, J=5.5 \mathrm{~Hz}, 2 \mathrm{H}), 3.52-3.45(\mathrm{~m}, 2 \mathrm{H}), 1.69-1.63(\mathrm{~m}, 2 \mathrm{H})$, $1.24(\mathrm{~s}, 12 \mathrm{H}), 1.20(\mathrm{~s}, 6 \mathrm{H}) .{ }^{13} \mathrm{C}$ NMR $\left(75 \mathrm{MHz},\left[\mathrm{D}_{6}\right] \mathrm{DMSO}\right): \delta=152.3$, $146.1,133.8,131.6,131.1,129.5,128.0,125.8,112.0,111.4,109.8$ 102.7, 100.8, 82.8 (2 C), 64.9, 49.9, 46.0, 36.2, 31.3, 30.2 (4 C), 24.7 (2 C). HRMS-ESI $(\mathrm{m} / \mathrm{z})$ calcd for $\mathrm{C}_{27} \mathrm{H}_{36} \mathrm{BN}_{2} \mathrm{O}_{3}{ }^{+}: 447.28135[\mathrm{M}+\mathrm{H}]^{+}$, found: 447.28125 .

\section{1-(2-((1H-Indol-5-yl)oxy)ethyl)-4,4-dimethyl- 7-(4,4,5,5-tetramethyl-1,3,2-dioxaborolan-2-yl)- 1,2,3,4-tetrahydroquinoline (8c)}

Following method $\mathrm{G}$, the reaction of 1-(2-((1H-indol-5-yl)oxy)ethyl)7-bromo-4,4-dimethyl-1,2,3,4-tetrahydroquinoline 6 c (260 mg, $0.65 \mathrm{mmol}$ ), bis(pinacolato)diboron $(198 \mathrm{mg}, 0.78 \mathrm{mmol}), \mathrm{KOAc}$ (319 mg, $3.25 \mathrm{mmol}$ ) and $\mathrm{PdCl}_{2}(\mathrm{dppf})(33.60 \mathrm{mg}, 0.05 \mathrm{mmol}$ ) in dioxane $(3.40 \mathrm{~mL})$ afforded, after purification by flash chromatography on silica gel (cyclohexane/ethyl acetate 80:20), the title compound $8 \mathrm{C}$ as a white solid (198 mg, $68 \%$ ); m.p. $194^{\circ} \mathrm{C}$. ${ }^{1} \mathrm{H}$ NMR (300 MHz, [D $\left.\left.\mathrm{D}_{6}\right] \mathrm{DMSO}\right): \delta=10.91(\mathrm{~s}, 1 \mathrm{H}), 7.28-7.22(\mathrm{~m}, 2 \mathrm{H}), 7.14(\mathrm{~d}$, $J=7.6,1 \mathrm{H}), 7.08-6.99(\mathrm{~m}, 2 \mathrm{H}), 6.87(\mathrm{~d}, J=7.6 \mathrm{~Hz}, 1 \mathrm{H}), 6.74(\mathrm{~d}, J=$ $8.6 \mathrm{~Hz}, 1 \mathrm{H}), 6.29(\mathrm{br}, 1 \mathrm{H}), 4.17-4.07(\mathrm{~m}, 2 \mathrm{H}), 3.71-3.62(\mathrm{~m}, 2 \mathrm{H}), 1.72-$ $1.59(\mathrm{~m}, 2 \mathrm{H}), 1.26(\mathrm{~s}, 12 \mathrm{H}), 1.20(\mathrm{~s}, 6 \mathrm{H}) .{ }^{13} \mathrm{C}$ NMR $\left(75 \mathrm{MHz}\right.$, [ $\left.\left.\mathrm{D}_{6}\right] \mathrm{DMSO}\right)$ : $\delta=152.3,143.2,134.1,131.1,128.0,125.8,125.2,121.9,119.4,116.5$, $111.9,111.4,102.8,100.8,83.3$ (2 C), 65.1, 50.3, 45.7, 36.3, 31.8, 30.3 (2 C), $24.7(4 \mathrm{C})$. HRMS-ESI $(\mathrm{m} / \mathrm{z})$ calcd for $\mathrm{C}_{27} \mathrm{H}_{36} \mathrm{BN}_{2} \mathrm{O}_{3}{ }^{+}: 447.28135$ $[\mathrm{M}+\mathrm{H}]^{+}$, found: 447.27817 .

\section{Method H: Suzuki coupling of 2-bromopyridine (9a-c)}

A mixture of boronate ester 8 or 10 (1.3 equiv), 2-bromopyridine (1.0 equiv) and $\mathrm{Na}_{2} \mathrm{CO}_{3}$ (2.5 equiv) in dioxane and water was degassed with argon. $\mathrm{PdCl}_{2}$ (dppf) (0.07 equiv) was then added and the resulting mixture was stirred $5 \mathrm{~h}$ at $100^{\circ} \mathrm{C}$. The mixture was cooled to RT, filtered through a pad of dicalite and extracted with ethyl acetate. Combined organic extracts were washed with brine and dried with $\mathrm{MgSO}_{4}$. After evaporation under reduced pressure, the crude product was purified by flash chromatography on silica gel.

\section{1-(2-((1H-Indol-5-yl)oxy)ethyl)-4,4-dimethyl-5-(pyridin-2-yl)-} 1,2,3,4-tetrahydroquinoline (9a)

Following method $\mathrm{H}$, the reaction of $1-(2-((1 H$-indol-5-yl)oxy)ethyl)5-(5,5-dimethyl-1,3,2-dioxaborinan-2-yl)-4,4-dimethyl-1,2,3,4-tetrahydroquinoline $10(30 \mathrm{mg}, 0.069 \mathrm{mmol}), 2$-bromopyridine $(5.1 \mu \mathrm{L}$, $0.053 \mathrm{mmol}), \mathrm{Na}_{2} \mathrm{CO}_{3}(14 \mathrm{mg}, 0.133 \mathrm{mmol})$ and $\mathrm{PdCl}_{2}(\mathrm{dppf})(3 \mathrm{mg}$, $0.004 \mathrm{mmol})$ in dioxane $(0.34 \mathrm{~mL})$ and water $(0.09 \mathrm{~mL})$ afforded, after purification by flash chromatography on silica gel (cyclohexane/ethyl acetate 60:40), the title compound $9 \mathrm{a}$ as a light yellow solid $(15 \mathrm{mg}, 71 \%)$; m.p. $56^{\circ} \mathrm{C}$. HPLC purity: $98.2 \%, t_{R}=$ $17.39 \mathrm{~min} .{ }^{1} \mathrm{H}$ NMR (300 MHz, [D $\mathrm{D}_{6}$ DMSO): $\delta=10.90(\mathrm{~s}, 1 \mathrm{H}), 8.61(\mathrm{~d}$ $J=4.6 \mathrm{~Hz}, 1 \mathrm{H}), 7.83-7.74(\mathrm{~m}, 2 \mathrm{H}), 7.41-7.35(\mathrm{~m}, 1 \mathrm{H}), 7.32-7.17(\mathrm{~m}$, $5 \mathrm{H}), 7.06(\mathrm{~d}, J=1.9 \mathrm{~Hz}, 1 \mathrm{H}), 6.73(\mathrm{dd}, J=8.7,2.2 \mathrm{~Hz}, 1 \mathrm{H}), 6.32-6.25$ $(\mathrm{m}, 1 \mathrm{H}), 4.21(\mathrm{t}, J=5.8 \mathrm{~Hz}, 2 \mathrm{H}), 3.79(\mathrm{t}, J=5.8 \mathrm{~Hz}, 2 \mathrm{H}), 3.52-3.44(\mathrm{~m}$, $2 \mathrm{H}), 1.75-1.68(\mathrm{~m}, 2 \mathrm{H}), 1.25(\mathrm{~s}, 6 \mathrm{H}) .{ }^{13} \mathrm{C}$ NMR $\left(75 \mathrm{MHz},\left[\mathrm{D}_{6}\right] \mathrm{DMSO}\right)$ : $\delta=156.9,152.3,149.2,143.9,137.1,136.8,131.7,131.1,128.0,126.1$, $125.8,122.0,120.0,113.9,112.0,111.5,108.6,102.8,100.8,65.0$, $50.2,45.9,36.4,31.6,30.4(2 \mathrm{C})$. HRMS-ESI $(\mathrm{m} / \mathrm{z})$ calcd for $\mathrm{C}_{26} \mathrm{H}_{28} \mathrm{~N}_{3} \mathrm{O}^{+}$ : $398.22269[\mathrm{M}+\mathrm{H}]^{+}$, found: 398.22185 .

\section{1-(2-((1H-Indol-5-yl)oxy)ethyl)-4,4-dimethyl-6-(pyridin-2-yl)- 1,2,3,4-tetrahydroquinoline (9b)}

Following method $\mathbf{H}$, the reaction of $1-(2-((1 H$-indol-5-yl)oxy)ethyl)4,4-dimethyl-6-(4,4,5,5-tetramethyl-1,3,2-dioxaborolan-2-yl)-1,2,3,4tetrahydroquinoline $8 \mathrm{~b} \quad(70 \mathrm{mg}, 0.157 \mathrm{mmol}), 2$-bromopyridine $(12 \mu \mathrm{L}, 0.12 \mathrm{mmol}), \mathrm{Na}_{2} \mathrm{CO}_{3}(32 \mathrm{mg}, 0.30 \mathrm{mmol})$ and $\mathrm{PdCl}_{2}(\mathrm{dppf})$ $(6.2 \mathrm{mg}, 0.08 \mathrm{mmol})$ in dioxane $(0.80 \mathrm{~mL})$ and water $(0.21 \mathrm{~mL})$ afforded, after purification by flash chromatography on silica gel (cyclohexane/ethyl acetate 75:25), the title compound $\mathbf{9 b}$ as a yellow oil ( $45 \mathrm{mg}, 94 \%$ ). HPLC purity: $99.9 \%, t_{\mathrm{R}}=17.15 \mathrm{~min}$. ${ }^{1} \mathrm{H}$ NMR (300 MHz, [D 6 ]DMSO): $\delta=10.92(\mathrm{~s}, 1 \mathrm{H}), 8.54(\mathrm{~d}, J=4.6 \mathrm{~Hz}, 1 \mathrm{H}), 7.93$ $(\mathrm{d}, J=2.1 \mathrm{~Hz}, 1 \mathrm{H}), 7.81-7.67(\mathrm{~m}, 3 \mathrm{H}), 7.26(\mathrm{dd}, J=5.4,2.7 \mathrm{~Hz}, 2 \mathrm{H})$ 7.18-7.11 (m, 1H), $7.05(\mathrm{~d}, J=2.3 \mathrm{~Hz}, 1 \mathrm{H}), 6.77(\mathrm{~d}, J=8.8 \mathrm{~Hz}, 1 \mathrm{H})$, $6.72(\mathrm{dd}, J=8.8,2.4 \mathrm{~Hz}, 1 \mathrm{H}), 6.32-6.27(\mathrm{~m}, 1 \mathrm{H}), 4.17(\mathrm{t}, J=5.6 \mathrm{~Hz}$, $2 \mathrm{H}), 3.76(\mathrm{t}, J=5.5 \mathrm{~Hz}, 2 \mathrm{H}), 3.54-3.44(\mathrm{~m}, 2 \mathrm{H}), 1.76-1.64(\mathrm{~m}, 2 \mathrm{H})$, $1.28(\mathrm{~s}, 6 \mathrm{H}) .{ }^{13} \mathrm{C}$ NMR $\left(75 \mathrm{MHz},\left[\mathrm{D}_{6}\right] \mathrm{DMSO}\right): \delta=156.7,152.3,149.0$ $144.5,136.8,131.1,130.5,128.0,125.8,125.3,125.1,123.9,120.5$, $118.4,112.0,111.5,110.6,102.8,100.8,65.1,50.1,46.0,36.3,31.7$, 30.3 (2 C). HRMS-ESI $(\mathrm{m} / \mathrm{z})$ calcd for $\mathrm{C}_{26} \mathrm{H}_{28} \mathrm{~N}_{3} \mathrm{O}^{+}: 398.22269[\mathrm{M}+\mathrm{H}]^{+}$, found: 398.22189 .

\section{1-(2-((1H-Indol-5-yl)oxy)ethyl)-4,4-dimethyl-7-(pyridin-2-yl)- 1,2,3,4-tetrahydroquinoline (9c)}

Following method $\mathbf{H}$, the reaction of $1-(2-((1 H$-indol-5-yl)oxy)ethyl)4,4-dimethyl-7-(4,4,5,5-tetramethyl-1,3,2-dioxaborolan-2-yl)-1,2,3,4tetrahydroquinoline $8 \mathrm{c} \quad(50 \mathrm{mg}, 0.11 \mathrm{mmol}), 2$ 2-bromopyridine $(8.20 \mu \mathrm{L}, 0.086 \mathrm{mmol}), \mathrm{Na}_{2} \mathrm{CO}_{3}(23 \mathrm{mg}, 0.22 \mathrm{mmol})$ and $\mathrm{PdCl}_{2}(\mathrm{dppf})$ $(5 \mathrm{mg}, 0.006 \mathrm{mmol})$ in dioxane $(0.60 \mathrm{~mL})$ and water $(0.15 \mathrm{~mL})$ afforded, after purification by flash chromatography on silica gel (cyclohexane/ethyl acetate 75:25), the title compound $9 \mathrm{c}$ as a yellow oil ( $8 \mathrm{mg}, 18 \%)$. HPLC purity: $99.0 \%, t_{\mathrm{R}}=17.63 \mathrm{~min}$. ${ }^{1} \mathrm{H}$ NMR (300 MHz, [D $]$ DMSO): $\delta=10.91(\mathrm{br}, 1 \mathrm{H}), 8.61(\mathrm{~d}, J=4.8 \mathrm{~Hz}, 1 \mathrm{H})$, $7.81-7.73(\mathrm{~m}, 2 \mathrm{H}), 7.38(\mathrm{~d}, J=1.2 \mathrm{~Hz}, 1 \mathrm{H}), 7.33-7.18(\mathrm{~m}, 5 \mathrm{H}), 7.07(\mathrm{~d}$, $J=2.4 \mathrm{~Hz}, 1 \mathrm{H}), 6.73(\mathrm{dd}, J=8.7,2.4 \mathrm{~Hz}, 1 \mathrm{H}), 6.31-6.25(\mathrm{~m}, 1 \mathrm{H}), 4.20$ $(\mathrm{t}, J=5.7 \mathrm{~Hz}, 2 \mathrm{H}), 3.79(\mathrm{t}, J=5.7 \mathrm{~Hz}, 2 \mathrm{H}), 3.52-3.43(\mathrm{~m}, 2 \mathrm{H}), 1.76-1.66$ $(\mathrm{m}, 2 \mathrm{H}), 1.25$ (s, 6H). ${ }^{13} \mathrm{C}$ NMR $\left(75 \mathrm{MHz},\left[\mathrm{D}_{6}\right] \mathrm{DMSO}\right): \delta=156.9,152.3$, $149.3,143.9,137.1,136.9,131.7,131.1,128.0,126.1,125.8,122.0$ 120.0, 113.9, 112.0, 111.5, 108.6, 102.8, 100.8, 65.0, 50.2, 45.9, 36.4, 31.6, 30.4 (2 C). HRMS-ESI (m/z) calcd for $\mathrm{C}_{26} \mathrm{H}_{28} \mathrm{~N}_{3} \mathrm{O}^{+}: 398.22269[\mathrm{M}$ $+\mathrm{H}]^{+}$, found: 398.21985 . 
1-(2-((1H-Indol-5-yl)oxy)ethyl)-5-(5,5-dimethyl1,3,2-dioxaborinan-2-yl)-4,4-dimethyl-

\section{1,2,3,4-tetrahydroquinoline (10)}

Following method $\mathrm{G}$, the reaction of 1-(2-((1H-indol-5-yl)oxy)ethyl)5-bromo-4,4-dimethyl-1,2,3,4-tetrahydroquinoline 6 a $\quad(400 \mathrm{mg}$, $1.00 \mathrm{mmol}$ ), bis(neopentyl glycolato)diboron $(271 \mathrm{mg}, 1.20 \mathrm{mmol})$, $\mathrm{KOAC}(491 \mathrm{mg}, 5.00 \mathrm{mmol})$ and $\mathrm{PdCl}_{2}(\mathrm{dppf})(51 \mathrm{mg}, 0.07 \mathrm{mmol})$ in dioxane $(8.60 \mathrm{~mL})$ afforded, after purification by flash chromatography on silica gel (cyclohexane/ethyl acetate $80: 20$ ), the title compound 10 as a light yellow solid (124 mg, $29 \%)$; m.p. $77^{\circ} \mathrm{C}$. HPLC purity: $96.6 \%, t_{\mathrm{R}}=24.31 \mathrm{~min} .{ }^{1} \mathrm{H}$ NMR $\left(300 \mathrm{MHz}\right.$, $\left.\left[\mathrm{D}_{6}\right] \mathrm{DMSO}\right)$ : $\delta=10.89(\mathrm{br}, 1 \mathrm{H}), 7.28-7.23(\mathrm{~m}, 2 \mathrm{H}), 7.03(\mathrm{~d}, J=2.4 \mathrm{~Hz}, 1 \mathrm{H}), 6.90$ (dd, $J=8.4,7.1 \mathrm{~Hz}, 1 \mathrm{H}), 6.70(\mathrm{dd}, J=8.7,2.4 \mathrm{~Hz}, 1 \mathrm{H}), 6.65(\mathrm{dd}, J=8.4$, $1.0 \mathrm{~Hz}, 1 \mathrm{H}), 6.47(\mathrm{dd}, J=7.1,1.0 \mathrm{~Hz}, 1 \mathrm{H}), 6.31-6.27(\mathrm{~m}, 1 \mathrm{H}), 4.12(\mathrm{t}$, $J=5.7 \mathrm{~Hz}, 2 \mathrm{H}), 3.73-3.64(\mathrm{~m}, 6 \mathrm{H}), 3.48-3.41(\mathrm{~m}, 2 \mathrm{H}), 1.67-1.59(\mathrm{~m}$, $2 \mathrm{H}), 1.27(\mathrm{~s}, 6 \mathrm{H}), 1.00(\mathrm{~s}, 6 \mathrm{H}) .{ }^{13} \mathrm{C}$ NMR $\left(75 \mathrm{MHz},\left[\mathrm{D}_{6}\right] \mathrm{DMSO}\right): \delta=$ $152.4,143.1,137.5,132.5,131.1,128.0,125.8,125.7,119.5,111.9$, $111.4,106.0,102.7,100.8,71.5$ (2 C), 65.0, 50.5, 45.7, 38.0, 32.8, 31.3, 29.8 (2 C), 21.5 (2 C). HRMS-ESI $(\mathrm{m} / \mathrm{z})$ calcd for $\mathrm{C}_{27} \mathrm{H}_{36} \mathrm{BN}_{2} \mathrm{O}_{3}{ }^{+}$: 433.26570 $[\mathrm{M}+\mathrm{H}]^{+}$, found: 433.26455 .

\section{4,4-Dimethyl-8-(pyridin-3-yl)-1,2,3,4-tetrahydroquinoline (11d)}

Following method $F$, the reaction of 8-bromo-4,4-dimethyl-1,2,3,4tetrahydroquinoline $3 \mathrm{~d}(500 \mathrm{mg}, 2.08 \mathrm{mmol})$, pyridin-3-ylboronic acid (768 mg, $6.25 \mathrm{mmol}), \mathrm{K}_{2} \mathrm{CO}_{3}(864 \mathrm{mg}, 6.25 \mathrm{mmol})$ and $\mathrm{PdCl}_{2}\left(\mathrm{PPh}_{3}\right)_{2}(146 \mathrm{mg}, 0.208 \mathrm{mmol})$ in DMF $(30 \mathrm{~mL})$ and water $(6 \mathrm{~mL})$ afforded, after purification by flash chromatography on silica gel (cyclohexane/ethyl acetate 60:40), the title compound $11 \mathrm{~d}$ as an orange solid (389 mg, $78 \%) ;$ m.p. $88^{\circ} \mathrm{C} .{ }^{1} \mathrm{H}$ NMR $\left(300 \mathrm{MHz},\left[\mathrm{D}_{6}\right]\right.$ DMSO): $\delta=8.55-8.50(\mathrm{~m}, 2 \mathrm{H}), 7.78$ (ddd, $J=7.8,2.2,1.8 \mathrm{~Hz}, 1 \mathrm{H}$ ), 7.43 (ddd, $J=7.8,4.8,0.9 \mathrm{~Hz}, 1 \mathrm{H}$ ), 7.19 (dd, $J=7.8,1.4 \mathrm{~Hz}, 1 \mathrm{H}$ ), 6.77 (dd, $J=7.6,1.4 \mathrm{~Hz}, 1 \mathrm{H}), 6.58(\mathrm{dd}, J=7.8,7.6 \mathrm{~Hz}, 1 \mathrm{H}), 5.01$ (brs, $1 \mathrm{H})$, 3.17-3.09 (m, 2H), 1.66-1.58 (m, 2H), $1.26(\mathrm{~s}, 6 \mathrm{H}) .{ }^{13} \mathrm{C}$ NMR $(75 \mathrm{MHz}$, [D ${ }_{6}$ DMSO): $\delta=149.8,147.8,141.3,136.7,135.6,129.8,128.0,126.2$ 123.7, 122.3, 115.6, 37.6, 36.4, 31.8, 31.1 (2 C). HRMS-ESI (m/z) calcd for $\mathrm{C}_{16} \mathrm{H}_{19} \mathrm{~N}_{2}{ }^{+}: 239.15428[\mathrm{M}+\mathrm{H}]^{+}$, found: 239.15213 .

\section{4,4-Dimethyl-8-(pyridin-4-yl)-1,2,3,4-tetrahydroquinoline (11 d')}

Following method $\mathrm{F}$, the reaction of 8-bromo-4,4-dimethyl-1,2,3,4tetrahydroquinoline $\mathbf{3 d}$ (367 mg, $1.53 \mathrm{mmol})$, pyridin-4-ylboronic acid $(563 \mathrm{mg}, 4.58 \mathrm{mmol}), \mathrm{K}_{2} \mathrm{CO}_{3}(633 \mathrm{mg}, 4.58 \mathrm{mmol})$ and $\mathrm{PdCl}_{2}\left(\mathrm{PPh}_{3}\right)_{2} \quad(107 \mathrm{mg}, 0.15 \mathrm{mmol})$ in DMF $(22 \mathrm{~mL})$ and water $(4.50 \mathrm{~mL})$ afforded, after purification by flash chromatography on silica gel (cyclohexane/ethyl acetate 60:40), the title compound $11 \mathrm{~d}^{\prime}$ as a yellow solid (320 mg, $88 \%$ ); m.p. $174^{\circ} \mathrm{C} .{ }^{1} \mathrm{H}$ NMR (300 MHz, [D $\left.\left.\mathrm{D}_{6}\right] \mathrm{DMSO}\right): \delta=8.60-8.56(\mathrm{~m}, 2 \mathrm{H}), 7.42-7.38(\mathrm{~m}, 2 \mathrm{H}), 7.20$ $(\mathrm{dd}, J=7.6,1.6 \mathrm{~Hz}, 1 \mathrm{H}), 6.80(\mathrm{dd}, J=7.6,1.6 \mathrm{~Hz}, 1 \mathrm{H}), 6.58(\mathrm{dd}, J=7.6$, $7.6 \mathrm{~Hz}, 1 \mathrm{H}), 5.13(\mathrm{~s}, 1 \mathrm{H}), 3.19-3.10(\mathrm{~m}, 2 \mathrm{H}), 1.67-1.59(\mathrm{~m}, 2 \mathrm{H}), 1.26(\mathrm{~s}$, $6 \mathrm{H}) .{ }^{13} \mathrm{C}$ NMR $\left(75 \mathrm{MHz},\left[\mathrm{D}_{6}\right] \mathrm{DMSO}\right): \delta=149.9$ (2 C), 147.6, 140.8, $130.0,127.6,126.6,124.1(2 \mathrm{C}), 123.0,115.6,37.6,36.3,31.8,31.0$ (2 C). HRMS-ESI $(\mathrm{m} / \mathrm{z})$ calcd for $\mathrm{C}_{16} \mathrm{H}_{19} \mathrm{~N}_{2}{ }^{+}: 239.15428[\mathrm{M}+\mathrm{H}]^{+}$, found: 239.15334.

\section{1-(2-((1-Benzyl-1H-indol-5-yl)oxy)ethyl)-4,4-dimethyl-8-(pyridin-} 3-yl)-1,2,3,4-tetrahydroquinoline (12d)

Following method $\mathrm{D}$, the reaction of 2-((1-benzyl-1H-indol-5-yl)oxy) ethanol $4(0.37 \mathrm{~g}, 1.37 \mathrm{mmol})$, IBX (1.15 g, $4.11 \mathrm{mmol})$, 4,4-dimethyl8-(pyridin-3-yl)-1,2,3,4-tetrahydroquinoline $11 \mathrm{~d}(0.69 \mathrm{~g}, 2.89 \mathrm{mmol}$ ), $\mathrm{NaBH}(\mathrm{OAC})_{3}(0.58 \mathrm{~g}, 2.74 \mathrm{mmol})$ in dry 1,2-DCE $(6.00 \mathrm{~mL})$ afforded, after purification by flash chromatography on silica gel (cyclohexane/ethyl acetate 70:30), the title compound $12 \mathrm{~d}$ as a light yellow oil (100 mg, $15 \%)$. ${ }^{1} \mathrm{H}$ NMR $\left(300 \mathrm{MHz},\left[\mathrm{D}_{6}\right] \mathrm{DMSO}\right): \delta=$ $8.68(\mathrm{brs}, 1 \mathrm{H}), 8.50(\mathrm{brd}, J=4.0 \mathrm{~Hz}, 1 \mathrm{H}), 7.90$ (ddd, $J=7.9,1.9$, $1.8 \mathrm{~Hz}, 1 \mathrm{H}), 7.46-7.42(\mathrm{~m}, 2 \mathrm{H}), 7.36(\mathrm{dd}, J=6.1,3.3 \mathrm{~Hz}, 1 \mathrm{H}), 7.33-$ $7.21(\mathrm{~m}, 4 \mathrm{H}), 7.19-7.13(\mathrm{~m}, 2 \mathrm{H}), 7.00-6.94(\mathrm{~m}, 2 \mathrm{H}), 6.72(\mathrm{~d}, J=2.4 \mathrm{~Hz}$, $1 \mathrm{H}), 6.49(\mathrm{dd}, J=8.8,2.4 \mathrm{~Hz}, 1 \mathrm{H}), 6.36(\mathrm{~d}, J=3.1 \mathrm{~Hz}, 1 \mathrm{H}), 5.34(\mathrm{~s}, 2 \mathrm{H})$, $3.46(\mathrm{t}, J=6.3 \mathrm{~Hz}, 2 \mathrm{H}), 3.26-3.16(\mathrm{~m}, 2 \mathrm{H}), 2.92(\mathrm{t}, J=6.3 \mathrm{~Hz}, 2 \mathrm{H})$, 1.73-1.63 (m, 2H), $1.30(\mathrm{~s}, 6 \mathrm{H}) .{ }^{13} \mathrm{C}$ NMR $\left(75 \mathrm{MHz},\left[\mathrm{D}_{6}\right] \mathrm{DMSO}\right): \delta=$ $152.2,149.0,145.0,145.2,138.6,138.4,137.7,136.8,131.0,130.4$ $129.6,129.2,128.6,128.5$ (2 C), 127.3, 126.9 (2 C), 126.8, 123.8, 121.4, 111.6, 110.7, 103.2, 100.6, 66.0, 54.0, 49.2, 44.4, 33.5, 32.5, $31.2(2 \mathrm{C})$. HRMS-ESI ( $\mathrm{m} / \mathrm{z})$ calcd for $\mathrm{C}_{33} \mathrm{H}_{34} \mathrm{~N}_{3} \mathrm{O}^{+}: 488.26964[\mathrm{M}+\mathrm{H}]^{+}$, found: 488.26583 .

\section{1-(2-((1-Benzyl-1H-indol-5-yl)oxy)ethyl)-4,4-dimethyl-8-(pyridin-} 4-yl)-1,2,3,4-tetrahydroquinoline (12d')

Following method $\mathrm{D}$, the reaction of 2-((1-benzyl-1H-indol-5-yl)oxy) ethanol $4(0.65 \mathrm{mg}, 2.41 \mathrm{mmol})$, IBX (2.02 g, $2.28 \mathrm{mmol})$, 4,4-dimethyl-8-(pyridin-4-yl)-1,2,3,4-tetrahydroquinoline $\quad \mathbf{1 1} \mathbf{d}^{\prime} \quad(1.21 \mathrm{~g}$, $5.07 \mathrm{mmol}), \mathrm{NaBH}(\mathrm{OAC})_{3}(1.02 \mathrm{~g}, 4.82 \mathrm{mmol})$ in dry 1,2-DCE $(10 \mathrm{~mL})$ afforded, after purification by flash chromatography on silica gel (cyclohexane/ethyl acetate 60:40), the title compound $12 \mathrm{~d}^{\prime}$ as a yellow oil (164 mg, 14\%). ${ }^{1} \mathrm{H}$ NMR (300 MHz, [D 6 DMSO): $\delta=8.58-$ $8.54(\mathrm{~m}, 2 \mathrm{H}), 7.47-7.44(\mathrm{~m}, 2 \mathrm{H}), 7.43(\mathrm{~d}, J=3.0 \mathrm{~Hz}, 1 \mathrm{H}), 7.35(\mathrm{dd}, J=$ 4.7, $4.7 \mathrm{~Hz}, 1 \mathrm{H}), 7.33-7.12(\mathrm{~m}, 6 \mathrm{H}), 6.97-6.92(\mathrm{~m}, 2 \mathrm{H}), 6.73(\mathrm{~d}, J=$ $2.4 \mathrm{~Hz}, 1 \mathrm{H}), 6.47(\mathrm{dd}, J=8.9,2.4 \mathrm{~Hz}, 1 \mathrm{H}), 6.35(\mathrm{dd}, J=3.0,0.7 \mathrm{~Hz}, 1 \mathrm{H})$, $5.34(\mathrm{~s}, 2 \mathrm{H}), 3.57(\mathrm{t}, J=6.2 \mathrm{~Hz}, 2 \mathrm{H}), 3.29-3.19(\mathrm{~m}, 2 \mathrm{H}), 2.95(\mathrm{t}, J=$ $6.2 \mathrm{~Hz}, 2 \mathrm{H}), 1.75-1.64(\mathrm{~m}, 2 \mathrm{H}), 1.29(\mathrm{~s}, 6 \mathrm{H}) .{ }^{13} \mathrm{C}$ NMR $\left(75 \mathrm{MHz},\left[\mathrm{D}_{6}\right]\right.$ DMSO): $\delta=152.1,149.8,149.7$ (2 C), 144.7, 138.4 (2 C), 131.1, 130.6 129.6, 128.8, 128.6, 128.5 (2 C), 127.3, 126.9 (2 C), 126.9, 123.6 (2 C), 120.8, 111.5, 110.7, 103.2, 100.6, 65.9, 54.3, 49.2, 44.6, 33.9, 32.5, 31.0 (2 C). HRMS-ESI $(\mathrm{m} / \mathrm{z})$ calcd for $\mathrm{C}_{33} \mathrm{H}_{34} \mathrm{~N}_{3} \mathrm{O}^{+}: 488.26964[\mathrm{M}+\mathrm{H}]^{+}$, found: 488.26873 .

\section{1-(2-((1H-Indol-5-yl)oxy)ethyl)-4,4-dimethyl-8-(pyridin-3-yl)- 1,2,3,4-tetrahydroquinoline (13d)}

Following method $E$, the reaction of 1-(2-((1-benzyl-1H-indol-5-yl) oxy)ethyl)-4,4-dimethyl-8-(pyridin-3-yl)-1,2,3,4-tetrahydroquinoline $12 \mathrm{~d}(100 \mathrm{mg} ; 0.21 \mathrm{mmol})$ and $\mathrm{BuOK}(323 \mathrm{mg}, 2.87 \mathrm{mmol})$ in DMSO $(6.60 \mathrm{~mL})$ afforded, after purification by flash chromatography on silica gel (cyclohexane/ethyl acetate 70:30), the title compound $13 \mathrm{~d}$ as a white solid (64 mg, $77 \%$ ); m.p. $158^{\circ} \mathrm{C}$. HPLC purity: $97.3 \%$, $t_{\mathrm{R}}=18.54 \mathrm{~min} .{ }^{1} \mathrm{H}$ NMR (300 MHz, [ $\mathrm{D}_{6}$ ]DMSO): $\delta=10.90-10.87(\mathrm{~m}$, $1 \mathrm{H}), 8.65(\mathrm{dd}, J=2.3,0.7 \mathrm{~Hz}, 1 \mathrm{H}), 8.49(\mathrm{dd}, J=4.8,1.7 \mathrm{~Hz}, 1 \mathrm{H}), 7.87$ (ddd, $J=7.8,2.3,1.7 \mathrm{~Hz}, 1 \mathrm{H}$ ), 7.43 (ddd, $J=7.8,4.8,0.7 \mathrm{~Hz}, 1 \mathrm{H}$ ), 7.37 (dd, $J=5.9,3.6 \mathrm{~Hz}, 1 \mathrm{H}), 7.26(\mathrm{dd}, J=2.8,2.7 \mathrm{~Hz}, 1 \mathrm{H}), 7.19(\mathrm{~d}, J=$ $8.7 \mathrm{~Hz}, 1 \mathrm{H}), 7.00-6.95(\mathrm{~m}, 2 \mathrm{H}), 6.69(\mathrm{~d}, J=2.3 \mathrm{~Hz}, 1 \mathrm{H}), 6.47(\mathrm{dd}, J=$ 8.7, $2.3 \mathrm{~Hz}, 1 \mathrm{H}), 6.32-6.27(\mathrm{~m}, 1 \mathrm{H}), 3.45(\mathrm{t}, J=6.4 \mathrm{~Hz}, 2 \mathrm{H}), 3.25-3.19$ $(\mathrm{m}, 2 \mathrm{H}), 2.93(\mathrm{t}, J=6.4 \mathrm{~Hz}, 2 \mathrm{H}), 1.80-1.64(\mathrm{~m}, 2 \mathrm{H}), 1.30(\mathrm{~s}, 6 \mathrm{H}) .{ }^{13} \mathrm{C}$ NMR $\left(75 \mathrm{MHz},\left[\mathrm{D}_{6}\right] \mathrm{DMSO}\right): \delta=151.9,149.5,147.5,145.3,138.6$, $137.5,136.2,131.1,130.6,129.1,127.9,126.7,125.7,123.5,121.3$, $111.8,111.4,102.6,100.8,66.0,54.1,44.5,33.5,32.5,31.2$ (2 C). HRMS-ESI $(m / z)$ calcd for $\mathrm{C}_{26} \mathrm{H}_{28} \mathrm{~N}_{3} \mathrm{O}^{+}:[M+\mathrm{H}]^{+} 398.22269$, found: 398.21939 .

\section{1-(2-((1H-Indol-5-yl)oxy)ethyl)-4,4-dimethyl-8-(pyridin-4-yl)- 1,2,3,4-tetrahydroquinoline $\left(13 d^{\prime}\right)$}

Following method $\mathrm{E}$, the reaction of 1-(2-((1-benzyl-1H-indol-5-yl) oxy)ethyl)-4,4-dimethyl-8-(pyridin-4-yl)-1,2,3,4-tetrahydroquinoline $12 \mathrm{~d}^{\prime}(150 \mathrm{mg} ; 0.31 \mathrm{mmol}$ ) and $t$ BuOK $(484 \mathrm{mg}, 4.31 \mathrm{mmol})$ in DMSO $(9.60 \mathrm{~mL})$ afforded, after purification by flash chromatography on silica gel (cyclohexane/ethyl acetate 70:30), the title compound $13 d^{\prime}$ as a yellow oil (94 mg, 77\%). HPLC purity: $99.6 \%, t_{R}=$ 
18.20 min. ${ }^{~} \mathrm{H}$ NMR (300 MHz, [D $\left.\left.\mathrm{D}_{6}\right] \mathrm{DMSO}\right): \delta=10.88$ (brs, $1 \mathrm{H}$ ), 8.60 $8.56(\mathrm{~m}, 2 \mathrm{H}), 7.50-7.46(\mathrm{~m}, 2 \mathrm{H}), 7.36(\mathrm{dd}, J=5.9,3.5 \mathrm{~Hz}, 1 \mathrm{H}), 7.26$ $(\mathrm{dd}, J=2.8,2.7 \mathrm{~Hz}, 1 \mathrm{H}), 7.19(\mathrm{~d}, J=8.8 \mathrm{~Hz}, 1 \mathrm{H}), 6.99-6.92(\mathrm{~m}, 2 \mathrm{H})$, $6.72(\mathrm{~d}, J=2.4 \mathrm{~Hz}, 1 \mathrm{H}), 6.47(\mathrm{dd}, J=8.8,2.4 \mathrm{~Hz}, 1 \mathrm{H}), 6.31-6.27(\mathrm{~m}$, $1 \mathrm{H}), 3.57(\mathrm{t}, J=6.2 \mathrm{~Hz}, 2 \mathrm{H}), 3.30-3.21(\mathrm{~m}, 2 \mathrm{H}), 2.96(\mathrm{t}, J=6.2 \mathrm{~Hz}, 2 \mathrm{H})$, $1.75-1.65(\mathrm{~m}, 2 \mathrm{H}), 1.30(\mathrm{~s}, 6 \mathrm{H}) .{ }^{13} \mathrm{C}$ NMR $\left(75 \mathrm{MHz},\left[\mathrm{D}_{6}\right] \mathrm{DMSO}\right): \delta=$ $151.9,149.8,149.7$ (2 C), 144.8, 138.4, 131.1, 130.7, 128.9, 127.9, $126.9,125.8,123.7$ (2 C), 120.9, 111.8, 111.4, 102.7, 100.8, 65.9, 54.4, 44.6, 33.9, 32.5, 31.1 (2 C). HRMS-ESI (m/z) calcd for $\mathrm{C}_{26} \mathrm{H}_{28} \mathrm{~N}_{3} \mathrm{O}^{+}$: $398.22269[\mathrm{M}+\mathrm{H}]^{+}$, found: 398.22138 .

\section{Biology}

\section{Cell cultures and reagents}

K562, KU812, KCL-22, IM-sensitive (K562S), IM-resistant (K562R) BCR$A B L+$ cells and MV4-11 cells were obtained from the Deutshe Sammlung von Mikroorganismens und Zellkulturen (DSMZ). MOLM13 and HS-27a were obtained from the American Type Culture Collection (ATCC). All cell lines were obtained according to the supplier's recommendations. Cells were cultured in RPMI 1640 (Gibco/ThermoFisher), with 10\% fetal bovine serum (Thermoscientific/Sigma-Aldrich), $2 \mathrm{mM}$ glutamine (Gibco/ThermoFisherUSA), $100 \mathrm{U} / \mathrm{mL}$ penicillin and $100 \mu \mathrm{g} / \mathrm{mL}$ streptomycin (Gibco/ThermoFisher) at $37^{\circ} \mathrm{C}, 5 \% \mathrm{CO}_{2}$. Resistant cells were cultured with $1 \mu \mathrm{M} \mathrm{IM}$. IM was purchased from Selleckchem (Houston, USA). Bone marrow (BM) MSC, obtained from donors undergoing orthopedic surgery at the CHRU de Tours, were isolated and cultured as described. ${ }^{[4]}$ Informed consent was obtained before BM samples were taken. All experiments performed in this study were in accordance with the ethical standards of the National Research Committee and with the Helsinki Declaration. MSC were cultured in $\alpha$ MEM (Gibco/ThermoFisher), with $10 \%$ fetal bovine serum (Thermoscientific/SigmaAldrich), $2 \mathrm{mM}$ glutamine (Gibco/ThermoFisher), $100 \mathrm{U} / \mathrm{mL}$ penicillin, $100 \mu \mathrm{g} / \mathrm{mL}$ streptomycin (Gibco/ThermoFisher), $0.01 \%$ fungizone (Gibco/Thermofisher) and $0.005 \%$ fibroblast growth factor 2 (Gibco/ThermoFisher) at $37^{\circ} \mathrm{C}, 5 \% \mathrm{CO}_{2}$.

\section{Cell proliferation assays}

Cell viability and proliferation were studied using a MTT cell proliferation assay (Sigma-Aldrich). Briefly, $2 \times 10^{4}$ leukemic cells were cultured in $100 \mu \mathrm{L}$ of RPMI medium in 96 well plates and treated with $10 \mu \mathrm{M}$ of each drug for 24,48 and $72 \mathrm{~h}$. To determine the concentration-effect of the molecules, cells were treated with concentrations ranging from $100 \mathrm{nM}$ to $100 \mu \mathrm{M}$ for $48 \mathrm{~h}$. To determine drugs toxicity on stromal cells, $1 \times 10^{4} \mathrm{HS}-27 \mathrm{a}$ or $3.5 \times 10^{3}$ were cultured in 96 well plates, incubated for $24 \mathrm{~h}$ and then treated with concentrations ranging from $100 \mathrm{nM}$ to $100 \mu \mathrm{M}$ of drugs for $48 \mathrm{~h}$. Cells were then incubated with $10 \mu \mathrm{L}$ of MTT working solution $(5 \mathrm{~g} / \mathrm{L}$ of methylthiazolyldiphenyl-tetrazolium bromide) during $4 \mathrm{~h}$. Cells were lysed overnight at $37^{\circ} \mathrm{C}$ with $100 \mu \mathrm{L}$ of SDS $10 \%, \mathrm{HCl}$ $0.003 \%$. Optical density (OD) at $570 \mathrm{~nm}$ was then measured using a spectrophotometer CLARIOstar ${ }^{\circledR}$ (BMG Labtech, Offenburg, Germany). Living cells were also enumerated using the trypan blue dye exclusion method.

\section{Apoptosis analysis}

KU812 and MV4-11 cells were treated for $48 \mathrm{~h}$ with $3 \mu \mathrm{M}$ of each drugs and then washed with PBS, then stained $\left(10^{6}\right.$ cells) in buffer containing FITC-annexin $V$ and 7-amino-actinomycin D (7-AAD; Beckmann Coulter) for $15 \mathrm{~min}$ at $4{ }^{\circ} \mathrm{C}$ and analyzed by flow cytometry (Becton Dickinson Accuri ${ }^{\mathrm{TM}}$ C6 flow cytometer). The FlowJo $^{\oplus}$ software was used to analyze data.

\section{Western blot}

Cells were suspended in NP40 buffer (Bio-Rad, NY, USA), separated on SDS/PAGE and blotted onto nitrocellulose membrane. Blots were incubated with the following antibodies (Abs): P-Y694/699STAT5, Actin (Cell Signaling Technology), STAT5 (BD Transduction Laboratories, Franklin Lakes, USA), STAT5A and STAT5B (Zymed/ ThermoFisher Scientific). Membranes were developed with the ECL chemiluminescence detection system (GE Healthcare) using specific peroxidase (HRP) conjugated to rabbit or mouse IgG antibodies (Cell Signaling Technology).

\section{qRT-PCR analysis}

RNA samples were reverse-transcribed using SuperScript ${ }^{\oplus}$ VILO CDNA synthesis kit (Invitrogen, Carlsbad, USA) as recommended by the supplier. The resulting CDNAs were used for quantitative realtime PCR (qRT-PCR). PCR primers (PIM1: for $5^{\prime}-\mathrm{TTTCG}$ AGCAT GACGA AGAGA-3', rev 5'-GGGCC AAGCAC CATCT AAT-3'; CISH: for 5'-AGCCA AGACC TTCTC CTACC $\Pi$-1' ${ }^{\prime}$, rev $5^{\prime}$-TGGCA TCTTC TGCAG GTGT-3'; STAT5A: for 5'-TCCCT ATAAC ATGTA CCCAC A-3', rev 5'-ATGGT CTCAT CCAGG TCGAA-3'; STAT5B: for 5'-TGAAG GCCAC CATCA TCAG-3', rev 5'-TGTTC AAGAT CTCGC CACTG-3') were designed with the ProbeFinder software (Roche Applied Sciences) and used to amplify the RT-generated CDNAs. qRT-PCR analyses were performed on the Light Cycler 480 thermocycler II (Roche). GAPDH (glyceraldehyde-3-phosphate dehydrogenase), ACTB (actin beta) and RPL13 A (ribosomal protein L13 A) were used as reference genes for normalization of qRT-PCR experiments. Each reaction condition was performed in triplicate. Relative gene expression was analyzed using the $2-\Delta \Delta \mathrm{Ct}$ method. ${ }^{[48]}$

\section{Abbreviations}

\section{AKT protein kinase $B$}

AML acute myeloid leukemia

BCR-ABL breakpoint cluster region-Abelson

Bneop neopentylglycolato borane

Bpin pinacol borane

CML chronic myeloid leukemia

DCE dichloroethane

FLT3-ITD FMS-like tyrosine kinase 3-internal tandem duplication

\section{IBX 2-iodoxybenzoic acid}

IM imatinib mesylate

JAK2 Janus kinase 2

PIM1 proviral integration site for Moloney leukemia virus

$$
1
$$

PPAR $\gamma$ peroxisome proliferator-activated receptor gamma

RNAi interference ribonucleic acid

ROS reactive oxygen species

SAR structure-activity relationship

SMA-ZnPP styrene-maleic acid-copolymer conjugated ZnPP

STAT5 signal transducer and activator of transcription 5

THQ tetrahydroquinoline

TKI tyrosine kinase inhibitor 


\section{Acknowledgements}

This work was supported by the Region Centre - Val de Loire, the Fondation pour la Recherche Médicale (FRM, grant no. DCM20181039564), the Laboratory of excellence Labex SYNORG, ANR-11-LABX-0029 and La Ligue Contre le Cancer. We thank Emmanuel Pecnard for technical assistance.

\section{Conflict of Interest}

The authors declare no conflict of interest.

Keywords: inhibitors · medicinal chemistry · myeloid
leukemias $\cdot$ STAT5 $\cdot$ Suzuki coupling

1] K. D. Bunting, Front. Biosci. 2007, 12, 2807-2820.

[2] K. Shaui, J. Halpern, J. ten Hoeve, X. Rao, C. L. Sawyers, Oncogene 1996 13, 247-254.

[3] M. Mizuki, R. Fenski, H. Halfter, I. Matsumura, R. Schmidt, C. Muller, W. Gruning, K. Kratz-Albers, S. Serve, C. Steur, T. Buchner, J. Kienast, $Y$ Kanakura, W. E. Berdel, H. Serve, Blood 2000, 96, 3907-3914.

[4] C. James, V. Ugo, J. P. Le Couédic, J. Staerk, F. Delhommeau, C. Lacout, L. Garçon, H. Raslova, R. Berger, A. Bennaceur-Griscelli, J. L. Villeval, S. N Constantinescu, N. Casadevall, W. Vainchenker, Nature 2005, 434, 11441148 .

[5] M. Kontro, H. Kuusanmäki, S. Eldfors, T. Burmeister, E. I. Andersson, O. Bruserud, T. H. Brümmendorf, H. Edgren, B. T. Gjertsen, M. Itälä-Remes, et al., Leukemia 2014, 28, 1738-1742.

[6] B. J. Druker, S. Tamura, E. Buchdunger, S. Ohno, G. M. Segal, S. Fanning, J. Zimmermann, N. B. Lydon, Nat. Med. 1996, 2, 561-566.

[7] N. P. Shah, C. Tran, F. Y. Lee, P. Chen, D. Norris, C. L. Sawyers, Science. 2004, 305, 399-401.

[8] E. Weisberg, P. W. Manley, W. Breitenstein, J. Brüggen, S. W. CowanJacob, A. Ray, B. Huntly, D. Fabbro, G. Fendrich, E. Hall-Meyers, A. L. Kung, J. Mestan, G. Q. Daley, L. Callahan, L. Catley, C. Cavazza, A Mohammed, D. Neuberg, R. D. Wright, D. G. Gilliland, J. D. Griffin, Cancer Cell 2005, 7, 129-141.

[9] J. M. Golas, K. Arndt, C. Etienne, J. Lucas, D. Nardin, J. Gibbons, P. Frost, F. Ye, D. H. Boschelli, F. Boschelli, Cancer Res. 2003, 63, 375-381.

[10] C. L. Shamroe, J. M. Comeau, Ann. Pharmacother. 2013, 47, 1540-1546.

[11] T. Tauchi, K. Ohyashiki, Leuk. Res. 2004, 28, 6-7.

[12] R. Nimmanapalli, K. Bhalla, Curr. Opin. Oncol. 2002, 14, 616-620.

[13] S. W. Cowan-Jacob, V. Guez, G. Fendrich, J. D. Griffin, D. Fabbro, P. Furet, J. Liebetanz, J. Mestan, P. W. Manley, Mini-Rev. Med. Chem. 2004, 4, 285299.

[14] A. Hochhaus, Semin. Hematol. 2003, 40, 69-79.

[15] K.-H. Kang, S.-H. Kim, S.-Y. Choi, H.-L. Yoo, M.-Y. Lee, H.-Y. Song, K.-M. Kee, J.-H. Suh, S.-Y. Yang, E.-J. Jang, S.-E. Lee, D.-W. Kim, Leuk. Res. 2019 76, 87-93.

[16] P. D. Kottaridis, R. E. Gale, M. E. Frew, G. Harrison, S. E. Langabeer, A. A Belton, H. Walker, K. Wheatley, D.T. Bowen, A. K. Burnett, A. H. Goldstone, D. C. Linch, Blood 2001, 98, 1752-1760.

[17] R. M. Stone, Semin. Hematol. 2002, 39, 4-10.

[18] J. L. Shipley, J. N. Butera, Exp. Hematol. 2009, 37, 649-658.

[19] M. Andreeff, Expert Rev. Anticancer Ther. 2015, 15, 1-15.

[20] C. M. Thomas, P. Campbell, J. Oncol. Pharm. Pract. 2018, 0, 1-9.

[21] N. Daver, R. F. Schlenk, N. H. Russell, M. J. Levis, Leukemia 2019, 33, 299312.

[22] A. Berger, V. Sexl, P. Valent, R. Moriggl, Oncotarget 2014, 5, 9564-9576.

[23] M. Brachet-Botineau, M. Polomski, H. A. Neubauer, L. Juen, D. Hédou, M.-C. Viaud-Massuard, G. Prié, F. Gouilleux, Cancers 2020, 12, 240-287.

[24] C. Sillaber, F. Gesbert, D. A. Frank, M. Sattler, J. D. Griffin, Blood 2000, 95, 2118-2125.

[25] A. Hoelbl, C. Schuster, B. Kovacic, B. Zhu, M. Wickre, M. A. Hoelzl, S. Fajmann, F. Grebien, W. Warsch, G. Stengl, L. Hennighausen, V. Poli, H. Beug, R. Moriggl, V. Sexl, EMBO Mol. Med. 2010, 2, 98-110.
[26] D. Ye, N. Wolff, L. Li, S. Zhang, R. L. Ilaria, Blood 2006, 107, 4917-4925.

[27] D. Fabbro, Nat. Chem. Biol. 2012, 8, 228-229.

[28] A. Brady, S. Gibson, L. Rybicki, E. Hsi, Y. Saunthararajah, M. A. Sekeres, R. Tiu, E. Copelan, M. Kalaycio, R. Sobecks, J. Bates, A. S. Advani, Eur. J. Haematol. 2012, 89, 288-293.

[29] J. Müller, B. Sperl, W. Reindll, A. Kiessling, T. Berg, ChemBioChem 2008, 9, 723-727.

[30] N. Elumalai, A. Berg, K. Natarajan, A. Scharow, T. Berg, Angew. Chem. Int. Ed. 2015, 54, 4758-4763; Angew. Chem. 2015, 127, 4840-4845.

[31] B. D. G. Page, H. Khoury, R. C. Laister, S. Fletcher, M. Vellozo, A. Manzoli, P. Yue, J. Turkson, M. D. Minden, P. T. Gunning, J. Med. Chem. 2012, 55, 1047-1055.

[32] A. A. Cumaraswamy, A. M. Lewis, M. Geletu, A. Todic, D. B. Diaz, X. R. Cheng, C. E. Brown, R. C. Laister, D. Muench, K. Kerman, H. L. Grimes, M. D. Minden, P. T. Gunning, ACS Med. Chem. Lett. 2014, 5, 1202-1206.

[33] B. Wingelhofer, B. Maurer, E. C. Heyes, A. A. Cumaraswamy, A. BergerBecvar, E. D. De Araujo, A. Orlova, P. Freund, F. Ruge, J. Park, G. Tin, S Ahmar, C. H. Lardeau, I. Sadovnik, D. Bajusz, G. M. Keseru, F. Grebien, S. Kubicek, P. Valent, P. T. Gunning, R. Moriggl, Leukemia 2018, 32, 1135 1146.

[34] Z. Liao, L. Gu, J. Vergalli, S. A. Mariani, M. De Dominici, R. K. Lokareddy, A. Dagvadorj, P. Purushottamachar, P. A. McCue, E. Trabulsi, C. D. Lallas, S. Gupta, E. Ellsworth, S. Blackmon, A. Ertel, P. Fortina, B. Leiby, G. Xia, H. Rui, D. T. Hoang, L. G. Gomella, G. Cingolani, V. Njar, N. Pattabiraman, B. Calabretta, M. T. Nevalainen, Mol. Cancer Ther. 2015, 14, 1777-1793.

[35] E. A. Nelson, S. R. Walker, E. Weisberg, M. Bar-Natan, R. Barrett, L. B. Gashin, S. Terrell, J. L. Klitgaard, L. Santo, M. R. Addorio, B. L. Ebert, J. D. Griffin, D. A. Frank, Blood 2011, 117, 3421-3429.

[36] E. A. Nelson, S. R. Walker, M. Xiang, E. Weisberg, M. Bar-Natan, R. Barrett, S. Liu, S. Kharbanda, A. L. Christie, M. Nicolais, J. D. Griffin, R. M. Stone A. L. Kung, D. A. Frank, Genes Cancer 2012, 3, 503-511.

[37] R. Rondanin, D. Simoni, M. Maccesi, R. Romagnoli, S. Grimaudo, R. M. Pipitone, M. Meli, A. Cascio, M. Tolomeo, ChemMedChem 2017, 12, 1183-1190.

[38] J. M. Shipley, D. J. Waxman, Toxicol. Appl. Pharmacol. 2004, 199, 275284.

[39] S. Prost, M. Le Dantec, S. Augé, R. Le Grand, S. Derdouch, G. Auregan, N. Déglon, F. Relouzat, A. Aubertin, B. Maillere, I. Dusanter-fourt, M Kirszenbaum, J. Clin. Invest. 2008, 118, 1765-1775.

[40] S. Prost, F. Relouzat, M. Spentchian, Y. Ouzegdouh, J. Saliba, G. Massonnet, J. P. Beressi, E. Verhoeyen, V. Raggueneau, B. Maneglier, S Castaigne, C. Chomienne, S. Chrétien, P. Rousselot, P. Leboulch, Nature 2015, 525, 380-383.

[41] L. Juen, M. Brachet-Botineau, C. Parmenon, J. Bourgeais, O. Hérault, F. Gouilleux, M.-C. Viaud-Massuard, G. Prié, J. Med. Chem. 2017, 60, 61196136.

[42] M. Brachet-Botineau, M. Deynoux, N. Vallet, M. Polomski, L. Juen, O. Hérault, F. Mazurier, M.-C. Viaud-Massuard, G. Prié, F. Gouilleux, Cancers. 2019, 11, 2043-2059.

[43] W. Zhu, Q. Hu, N. Hanke, C. J. Van Koppen, R. W. Hartmann, J. Med. Chem. 2014, 57, 7811-7817.

[44] M. Boehm, E. Martinborough, M. Moorjani, J. Tamiya, L. Huang, A Yeager, E. Brahmachary, T. Fowler, A. Novak, P. Meghani, M. Knaggs, World patent WO 2014/201172, 2014.

[45] H.T.T. Pham, B. Maurer, M. Prchal-Murphy, R. Grausenburger, E. Grundschober, T. Javaheri, H. Nivarthi, A. Boersma, T. Kolbe, M. Elabd, F. Halbritter, J. Pencik, Z. Kazemi, F. Grebien, M. Hengstschläger, L. Kenner, S. Kubicek, M. Farlik, C. Bock, P. Valent, M. Müller, T. Rülicke, V. Sexl, R. Moriggl, J. Clin. Invest. 2018, 128, 387-401.

[46] T. Khanam, S. Sandmann, J. Seggewiss, C. M. Ruether, M. Zimmermann A. B. Norvil, C. Bartenhagen, G. Randau, S. Mueller, H. Herbrüggen, et al. Blood 2020, DOI: 10.1182/blood.2020005381.

[47] A. L. Ponte, T. Ribeiro-Fleury, V. Chabot, F. Gouilleux, A. Langonné, O. Hérault, P. Charbord, J. Domenech, Stem Cells Dev. 2012, 21, 3162-3172. [48] K. J. Livak, T. D. Schmittgen, Methods 2001, 25, 402-408.

Manuscript received: October 16, 2020

Accepted manuscript online: December 4, 2020

Version of record online: January 20, 2021 